\title{
CUSTOMER LOYALTY IN INDUSTRIAL CLUSTERS: PERCEIVED VALUE AND SATISFACTION AS ANTECEDENTS
}

\begin{abstract}
Purpose: This paper studies, from the perspective of relationship marketing, the loyalty behavior of industrial customers in the context of a cluster. Loyalty is a key variable for studying long term relationships between firms.

Research implications: Recent advances in consumer and services marketing consider that perceived value and satisfaction are central to explaining customer loyalty. However, very few studies in B2B explain the antecedents of customer loyalty. This study adopts the relationship marketing approach, and loyalty behavior is being analyzed in a specific setting: an industrial cluster. Furthermore, the effect of the number of suppliers is analyzed as a possible moderator in the relationships of the model.
\end{abstract}

Methodology Approach: We have chosen the Spanish tile cluster to test a series of the hypotheses. Questionnaires were elaborated from primary and secondary information and SEM has been used for statistical treatment and confirmatory factor analysis (CFA).

Findings: Importance relationships between perceived value, satisfaction and loyalty and the importance of the different dimensions of perceive value.

Practical implications: The empirical study and the results provide an importance evidence for managers: the critical influence of the Emotional and social perceived values by the customer on his level of satisfaction and on the achievement of final loyalty. And the importance in the commercial training programs of this matters.

Originality/value/contribution of the paper: The importance of the most intangibles dimensions of value for the industrial cluster relations between companies.

Key words: Loyalty, Cluster, Perceived value, Emotional value, Social value, Satisfaction 


\section{CUSTOMER LOYALTY IN INDUSTRIAL CLUSTERS: PERCEIVED VALUE AND SATISFACTION AS ANTECEDENTS}

\section{INTRODUCTION}

Achieving customer loyalty is the fundamental objective of any firm. From the seller's point of view, the customer's loyalty behavior takes the form of greater collaboration, fewer complaints, less sensitivity to price and, in sum, greater profitability of the customer (Dick and Basu, 1994; Zeithaml, Berry and Parasuraman, 1996; Yi and Jeon, 2003; Bennett, Härtel and McColl-Kennedy, 2005). Therefore, a long term relationship based on customer loyalty is a fundamental asset for any firm.

This is the relationship marketing approach, which maintains that the ultimate aim of marketing is to establish mutually beneficial relationships between buyers and sellers (Christopher, Payne and Ballantyne, 2002; LaPlaca, 2004). If one of the parties considers that it does not obtain benefits from the relationship, or that it gives more than it gets, it will seek alternatives. In this sense, one form of relationship marketing, Customer Relationship Management (CRM), implies the management of the mutually beneficial relationship from the seller's perspective.

But, as posited by the IMP Group, relationships occur in particular environments and conditions. Clusters were defined by Porter (2000) as "geographic concentrations of interconnected companies, specialized suppliers, service providers, and associated institutions in a particular field that are present in a nation or region". He adds: "clusters arise because they increase the productivity with which companies can compete".

Today's economic map of the world is characterized by clusters. The most famous examples are found in Silicon Valley and Hollywood. In industrial markets, the Italian Ceramic Tile cluster is an example closer to the aims of this study. Porter (1998) explains how clusters affect competition in three broad ways: first, by increasing and improving the productivity 
and the competitiveness of companies based in the area; second, by driving the direction and pace of innovation; and third, by stimulating the formation of new businesses within the cluster. Also, clusters have other benefits, like lower transaction costs. Geographical, cultural, and institutional proximity provides companies with special access, closer relationships, better information, powerful incentives, and other advantages that are difficult to tap from a distance (Ganesan, Malter and Rindfleisch, 2005).

The relationships occurring in a cluster are therefore a competitive advantage for the firms located in it (Emiliani, 2004). The study of the relationships formed in this context is a point of interest of the first order for industrial marketing. Interdependence and long term relationships in $\mathrm{B} 2 \mathrm{~B}$ are matters that have preoccupied marketing researchers (Cannon and Perreault, 1999; Lapierre, 2000; Eggert and Ulaga, 2002; Bonner and Calantone, 2005; Spiteri and Dion, 2004, Ganesan, Malter and Rindfleisch, 2005). Sophisticated formulas have arisen to manage relationships, such as just-in-time, outsourcing and partnership. But the majority of the relationships among firms in a cluster continue to be based on simpler formulas, in which mutual satisfaction plays a fundamental role. Many of the relationships in the cluster are still based on traditional situations of buying and selling, in the framework of a long term relationship, where different competitors try to conquer market share at the competition's expense. These are situations where delivery times, prices, personal relationships, and service quality play a fundamental role, where information and innovation are immediately shared (Lapierre, 2000; Eggert and Ulaga, 2002; Emiliani, 2004, Ulaga and Eggert, 2006). Every new transaction is based on both the satisfaction achieved in previous ones and on personal bonds, such that dissatisfaction is not the only reason for changing supplier (Bonner and Calantone, 2005; Spiteri and Dion, 2004). To sum up, the loyalty of the customer in his repeat purchase behaviors depends on the value offered by each competitor and on the satisfaction achieved with each one. 


\section{RATIONALE, AIM AND OBJECTIVES.}

Relationships in industrial markets have been an important line of research in marketing since the 1970s (LaPlaca, 2006). Outstanding work has been done by the IMP Group, whose studies have helped the understanding of dyadic relationships in B2B (Ford, 1980; Ford, Hakannson and Johanson, 1986; Hakannson, 1982; Metcalf, Frear and Krishnan, 1990; Hällen and Sandstróm, 1991; Sandström, 1992), and outstanding among these is the interactive model (Hakannson, 1982). Together with this perspective, in recent years a new complementary focus has emerged with the outlook of relationship marketing (Morgan and Hunt, 1994; Ravald and Grönroos, 1996; Sweeney and Webb, 2002; Eggert, Ulaga and Schultz, 2006; Plank and Newell, 2006).

Relationship marketing attempts to explain how long term relationships between firms and their customers are formed (Christopher, Payne and Ballantyne, 2002). Patronage studies analyze buyers' behavior so that the seller can improve customer relationships. One indicator of the importance of the subject is a recent special number of Industrial Marketing Management (2006, vol 35, issue 1) which analyzes the formalization of these long term relationships in partnerships from the relationship marketing perspective.

The explication of customer loyalty is the fundamental aim of relationship marketing. Recent advances in relationship marketing have highlighted the role of perceived value in achieving it (Gassenheimer, Houston and Davis, 1998; Sharma, Krishnan and Grewal, 2001; Ulaga and Chacour, 2001; Flint, Woodruff and Gardial, 2002; Lindgreen and Wynstra, 2005; Eggert, Ulaga and Schultz, 2006, Ulaga and Eggert, 2006). The Committee on Definitions of the American Marketing Association approved in 2004 a new definition of marketing (AMA, 2004) where value and managing customer relationships become the keystones of marketing. Managing relationships in B2B involves managing value (Anderson, 1995; Flint, Woodruff and Gardial, 2002; Eggert, Ulaga and Schultz, 2006). 
Satisfaction is a fundamental variable in marketing, to which the literature concedes a high power of explanation of customers' loyalty behavior (Andaleeb, 1996; Ravald and Grönroos, 1996; Henning-Thurau and Hansen, 2001; Bennett, Härtel and McColl-Kennedy, 2005). Satisfaction is seen to be a key mediating variable which helps to explain the level of loyalty that will lead to re-purchase or to cooperation between firms. This importance can be observed in two phenomena: the first is firms' continual monitoring of the satisfaction of their customers; and the second is the fundamental role played by customers' satisfaction in models of excellence like EFQM or Malcolm Baldrige's model.

Since the 1970s the Industrial Marketing and Purchasing Group (IMP Group) has studied the nature of relationships in markets. The interactive model highlights the role played by the atmosphere and the setting in which the relationships develop. These considerations have been taken into account in this paper. Clusters imply a certain environment in which long term relationships among firms develop. The relationships formed among the firms that make up an industrial cluster are complex. Geographical, cultural, and institutional proximity provides companies with special access, closer relationships, better information, powerful incentives, and other advantages. Together with this, the number of suppliers is an indicator of the atmosphere, since it may, for example, imply a greater or lesser dependence of the customer.

The aim of the paper is to study, from the point of view of relationship marketing, and on the basis of the perceived value of the relationship, the loyalty behavior of industrial customers in the context of a cluster. Together with this it aims to study the moderating role played by the number of suppliers.

More specifically we aim to achieve the following objectives:

1. To demonstrate that the customer's perceived value and customer's satisfaction are antecedents of customer's loyalty. 
2. To demonstrate the importance of personal, emotional and social elements in the customer relationships in a specific industrial interaction environment (cluster).

3. To analyze the moderating role of the number of suppliers (atmosphere) in the causal model.

\section{LITERATURE REVIEW AND CONCEPTUAL MODEL}

Loyalty is a multidimensional concept with a wider meaning than the concept of customer retention or cooperation, which only refers to the behavioral aspect of loyalty. It emerges dynamically as the optimal stage of evolution of the relationship between a customer and a supplier or a brand. The multidimensionality of the concept seems to be demonstrated in studies such as Dick and Basu (1994) or Zeithaml, Berry and Parasuraman (1996). The former identified two dimensions, attitudinal and behavioral loyalty, and the latter determined that loyalty had four dimensions: the intention to repurchase, positive references, complaint behavior, or sensitivity or tolerance to price against other alternatives. These dimensions thus seem to be indicators of the existence of a feeling of loyalty of one party to the other.

On the basis of these considerations, within the scope of relationship marketing, loyalty can be defined as the future behavior commitment to purchase a product or service (Bennett, Härtel and McColl-Kennedy, 2005), or "a deeply held commitment to rebuy or repatronize a preferred product or service consistently in the future, despite situational influences and marketing efforts having the potential to cause switching behavior" (Oliver, 1997, p. 392). From this perspective, loyalty can be measured directly, through purchase behavior, by observation of a higher frequency of purchase or the concatenation of a set of purchases of a product or service as against others where this does not occur; and indirectly, by measuring the attitude or intention to repurchase (Yi and Jeon, 2003).

Direct measurement involves a series of difficulties, as it is difficult to obtain information relating to a customer's sequence of purchases. If this is added to the fact that simple 
repetition of purchase is not a good indicator of loyalty, as not everybody who repeats a purchase can be considered a loyal customer, it seems that indirect measurement offers more reliable elements for the measurement of loyalty (Reichheld, 1996; Cronin, Brady and Hult, 2000; Hennig-Thurau and Hansen, 2001; Yi and Jeon, 2003). Indeed, the behavioral perspective is characterized by its purely mechanical view, which prevents it from providing valuable elements to explain the reasons for the adoption of a particular behavior, and so what researchers do is to register what the customer does but not what has led him/her to do it (Dick and Basu, 1994; Lacoeuilhe, 1997; Oliver, 1999; Rowley and Dawes, 2000; Diller, 2000).

An important point of interest in research into customer loyalty is the identification of its antecedents. Perceived value and satisfaction have been suggested in the literature as key elements in explaining loyalty behavior in industrial markets (Anderson, 1995; Heskett, Sasser and Schlesinger, 1997; Gassenheimer, Houston, and Davis, 1998; Flint, Woodruff and Gardial, 2002; Spiteri and Dion, 2004; Eggert, Ulaga and Schultz, 2006). The conceptual model proposed is shown in figure 1.

\section{FIGURE 1}

\subsection{Customer's Perceived Value}

Relationship marketing assigns a fundamental role to perceived value in the explanation of customer loyalty behavior. "Offering superior value to the customer is essential for creating and maintaining long-term customer-supplier relationships" (Sharma, Krishnan and Grewal, 2001; Eggert, Ulaga and Schultz, 2006). The AMA (2004) considers perceived value as the key element of marketing. In this sense, for authors as Prahalad and Ramaswamy (2004) and Vargo and Lusch, (2004) perceived value is always co-created in interaction, even though the value of such interactive experience is a matter for determination by the customer. 
Perceived value is a concept that has recently been receiving much attention from industrial marketing researchers (Metcalf, Frear and Krishnan, 1990; Anderson, Jain and Chintagunta, 1993; Parasuraman, 1997; Ravald and Grönross, 1996; Lapierre, 2000; Walter, Ritter and Germünden, 2001; Ulaga and Chacour, 2001, Eggert and Ulaga, 2002; Flint, Woodruff and Gardial, 2002; Ulaga and Eggert, 2003; Woodall, 2003; Anderson and Narus, 2004; Leonidou, 2004; Lindgreen and Wynstra, 2005; Ulaga and Eggert, 2006; Eggert, Ulaga and Schultz, 2006).

Nevertheless, the classical view conceives perceived value as a construct configured by two parts, one of benefits received (economic, social and relationship) and another of sacrifices made (price, time, effort, risk and convenience) by the customer (Dodds, Monroe and Grewal, 1991; Grewal, Monroe and Krishnan, 1998; Cronin et al., 1997; Cronin, Brady and Hult, 2000; Oh, 2003; Hinterhuber 2004).

Recently an approach based on the conception of perceived value as a multidimensional construct has been gaining ground (Rust, Zeithaml and Lemmon, 2000; De Ruyter et al., 1997; De Ruyter, Wetzels and Bloemer 1998; Sinha and DeSarbo, 1998; Sweeney and Soutar, 2001; Woodruff, 1997). This approach allows us to overcome some of the problems of the traditional approach to perceived value, particularly its excessive concentration on economic utility (Zeithaml, 1988). Another important aspect of the second approach is that it echoes the new theoretical developments in the area of organizational behavior, referring to the role played by feelings in buying and consumption habits.

Starting from the work by Sheth, Newman and Gross (1991a, 1991b), Sweeney, Soutar and Johnson (1999) and Sweeney and Soutar (2001) designed a scale of measurement for perceived value (PERVAL) as a multidimensional construct. The analyses of reliability and validity undertaken for the design of PERVAL resulted in the 5 dimensions proposed by Sheth, Newman and Gross (1991a, 1991b) being reduced to 3: functional, social and 
emotional, though in the functional dimension they identified 3 types (price, quality and versatility).

In recent papers, Eggert, Ulaga (2006) and Eggert, Ulaga and Schultz (2006) analyze the sources of value creation in business marketing. They go beyond the traditional view in B2B, focused on the physical product, and take into account the relational dimensions. Nevertheless, despite their multidimensional vision of perceived value, they do not take into account the social and emotional component.

Although in consumer markets the studies focused on perceived value seem to agree as to the existence of at least two dimensions, -one functional and another social, there is no such agreement in the case of industrial markets (Ulaga and Chacour, 2001, Eggert and Ulaga, 2002; Flint, Woodruff and Gardial, 2002; Ulaga and Eggert, 2003; Leonidou, 2004; Lindgreen and Wynstra, 2005). A review reveals some where the dimensions of perceived value are present, but not uniformly (Anderson, Jain and Chintagunta, 1993; Lapierre, 2000; Ulaga, 2001; Ulaga and Chacour, 2001; Flint and Woodruff, 2001; Hogan, 2001; Sharma, Krishnan and Grewal, 2001; Eggert and Ulaga, 2002; Ulaga and Eggert, 2003; Brenan, Turnbull and Wilson, 2003; Eggert, Ulaga and Schultz, 2006). Nevertheless, as in consumer markets, there seems to be an underlying dimensionality based on two factors, intangibles and tangibles. Thus in this study we have followed the line of research begun by Sheth, Newman, and Gross (1991a,b) and continued by Sweeney and Soutar (2001) and Eggert and Ulaga (2002), which differentiates between functional or cognitive dimensions, emotional or personal dimensions (Sweeney and Soutar, 2001; Eggert and Ulaga, 2002) and social dimensions (Lapierre, 2000). This approach leads us to put forward the first hypothesis of the study:

$\mathrm{H}_{1}$ : Perceived value in a cluster is a second order multidimensional construct consisting of three dimensions: functional, social and emotional. 
The first hypothesis considers perceived value as a second order construct, implying that each dimension is in turn made up of various sub-dimensions. The functional dimension of perceived value relates to the utility derived from the attributes of the products and services, information, delivery, service and personal interaction (Eggert, Ulaga and Schultz, 2006). The industrial customer obtains value from attributes such as product quality, service quality, or price (Sweeney, Soutar and Johnson 1999). This is an economic and rational analysis of comparison between benefits and sacrifices, a concept that agrees with the view of perceived value maintained by some authors (Lovelock, 1991; Anderson, Jain and Chintagunta, 1993; Cronin et al., 1997; Rust, Zeithaml and Lemmon, 2000). This perspective identifies the quality of the product and services as positive values or benefits, and price and other nonmonetary sacrifices as negative values (Berry, Seider, and Gresham, 2002). The functional dimension would therefore be a valuation almost equivalent to the quality/price ratio, but with the inclusion of a component of non-monetary sacrifice. The second hypothesis relating to the functional dimension is therefore as follows.

\footnotetext{
$\mathrm{H}_{2}$ : The functional dimension of perceived value in a cluster consists of a positive component (perceived quality) and a negative component (monetary and non-monetary costs).
}

The emotional dimension of perceived value is derived from the feelings and emotions that the product or service generates in the purchaser. Emotions play a crucial role in the initiation, the development and the sustainment of relations over time (Andersen and Kumar, 2006). This dimension, together with the social dimension, helps to explain why individuals and organizations do not always make decisions on the basis of a rational or functional valuation: it permits them to reduce their uncertainty and to generate feelings of trust (Hakannson, 1982). The individuals who make decisions in organizations allow themselves to be influenced by their emotions and affective states as well as by their social milieu (Nyer, 1997; De Chernatony, Harris and Dall'Olmo, 2000; Klemz and Boshoff, 2001). The emotional dimension in business markets has been studied by the IMP Group (Hakannson, 1982), but 
with another name -social exchange- and by the relationship marketing perspective (Geyskens, Steenkamp and Kumar, 1999; Sweeney and Soutar, 2001; Sweeney and Webb, 2002; Bennett, Härtel and McColl-Kennedy, 2005; Andersen and Kumar, 2006). On the basis of these studies and others (Sheth, Newman and Gross, 1991a; Brown, Lusch and Nicholson, 1995; Price, Arnauld and Deibler, 1995; Bagozzi, Gopinath and Nyer, 1999), we identify three factors: experience, personalized attention and interpersonal relationships. In the first place, the experience accumulated is a consequence of the exchange of sensory stimuli, information and emotions between firms and customers (Gardial et al., 1994; Schmitt, 1999; Sweeney and Soutar, 2001). It replaces the traditional stimuli, based in rational rewards, both in consumer markets (Holbrook and Hirschman, 1982; Schmitt, 1999), and in industrial markets (Brown, Lusch and Nicholson, 1995), and is a probable risk-reduction strategy (Bennett, Härtel and McColl-Kennedy, 2005). Personalized attention and interpersonal relations are derived from the literature that analyses the psychological benefits (Geyskens, Steenkamp and Kumar, 1999; Gwinner, Gremler, and Bitner, 1998; Andersen and Kumar, 2006) and the social benefits of establishing a relationship, whether at an individual level or at business level. Thus for Henning-Thurau and Hansen (2001), personalized attention forms part of the elements that are valued positively and continually by customers in their relations with firms. Also for Gwinner, Gremler and Bitner, (1998) and Henning-Thurau, Gwinner and Gremler (2002) personalized attention helps to reduce the feeling of anxiety, and to generate a situation of comfort as a consequence of the customers' knowledge of what they are going to receive in their dealings with the supplying firm (Hakannson, 1982). Interpersonal relationships are the capacity between firms and consumers of being understood mutually, of being able to develop social relationships between them. They are a way to socialize professional relationships, to increase dialogue between customers and firms, between providers and makers, (Prahalad y Ramaswamy, 2004). Recognition of the customer by the 
contact personnel of the supplier firm helps to anticipate in part the content of the relationship in its initial stages. Finally, interpersonal relationships seem to be closely linked to the above two factors, experience and personalized attention, and also help to generate pleasant feelings in the relationship with the supplying firm (Gwinner, Gremler and Bitner, 1998). The degree of interpersonal knowledge obtained in this process helps to dispel feelings of mistrust or anxiety in this context and to make relationships more fluid and lasting (Henning-Thurau, Gwinner and Gremler, 2002). Sweeney and Webb (2002) also agree in this, affirming that perceptions of affinity, friendship, or feelings of familiarity in the other party help to strengthen relationships among firms. Interpersonal relationships aid to increase the credibility, the honesty and reliability between the seller and the consumer company (Martín et al., 2004). The third hypothesis will therefore be:

\section{$\mathrm{H}_{3}$ : The emotional dimension of perceived value in a cluster is made up of experience, personalized} attention and interpersonal relationships.

Finally, the social dimension of perceived value has to do with the consequences in different target publics of the purchase and consumption of a product or service. In both consumer markets and industrial markets, there is a concern for one's own social projection (Lapierre, 2000; Sweeney and Soutar, 2001). The social perception of the firm's activity, and of the form and the results of its relationships, is becoming more and more important. Financial results are linked to the social valuation or acceptance of firms' activities (Flint, Woodruff and Gardial, 2002). In a cluster, the personal tools of marketing, capacity to personalize the service, responsiveness, technical competence, and attentiveness, are fundamental, and affect the perception of the firm. Together with the products offered by the company, the way in which these are offered is important. In this sense, the firm's image or reputation is at stake and becomes a key element of decision-making (Ganessan, 1994; Bonner and Calantote, 2005). For example, Lapierre (2000) considers that social value is the image based on reputation and on credibility and their social repercussions. As a complement, Allee (2000) 
suggests that perceived value should incorporate such important elements as social citizenship and corporate identity. Nguyen and Leblanc (2001) agree with Lapierre (2000) in identifying corporate reputation and social image as the determining factors of the social dimension. The social image transmitted and the reputation are therefore identified as the two factors underlying the social dimension (Sheth et al, 1991a; Anderson and Weitz, 1992; Ganesan, 1994). In this sense, we propose our fourth hypothesis:

$\mathrm{H}_{4}$ : The social dimension of perceived value in a cluster is formed by the reputation and the perceived social image.

\subsection{Customer's Satisfaction}

In an industrial context, satisfaction has been analyzed by various authors (Wilson, 1995; Nevin, 1995; Olsen, 2002; Hewett, Money and Sharma, 2002; Brenann, Turnbull and Wilson, 2003; Nijssen, Singh, Sirdeshmukh and Holzmüeller, 2003). Outstanding among them are the contributions by Gaski and Nevin (1985) and Frazier, Gill and Kale (1989) for whom satisfaction is the consequence of a plural valuation of many aspects that affect their working relationship with another agent or firm or within a more plural relationship. For these authors satisfaction has two facets, one economic and one social. Economic satisfaction would include the positive affective response of a member to the economic rewards to be derived from the relationship in which he or she is immersed. Social satisfaction, for its part, implies a positive affective response to the psychological aspects of the relationship. In this sense, a member decides to remain in the relationship, i.e. is satisfied, because he or she appreciates the contacts with the other party and likes working with them. It is due to his/her belief that the other party will be concerned, and willing to exchange ideas (Nevin, 1995; Geyskens, Steenkamp and Kumar, 1999).

Satisfaction in an industrial context is therefore directly or indirectly linked to the establishment of alliances or agreements between firms, and with the purpose of achieving a source of competitive advantages for the firms involved (Eriksson, Majkgard and Sharma, 
1999; Mohr and Spekman, 1994; Brennan, Turnbull and, Wilson, 2003). The fact of working together permits a broader outlook, and recognition of mutual dependence, which motivate the parties to work for the survival of the relationship. Opportunistic behavior by one of the parties will negatively affect the other, and the relationship as a whole. On the contrary, cooperative behavior will increase the results of the relationship, more than if each of the parties acted separately. The success of the relationship will depend on the behavior of one to the other, and the success of one depends partly on the other. Their efforts to co-operate will allow them to share information, opportunities and processes so as to facilitate the achievement of competitive advantages.

Thus, in the general field of industrial relationships, satisfaction is an affective state resulting from the overall valuation of all aspects of a working relationship between one firm and another (Anderson and Narus, 1984; Gaski and Nervin, 1985; Walter, Ritter and Gemünden, 2001).

\subsection{Loyalty, Perceived Value and Satisfaction}

Regarding the relationship between loyalty, perceived value and satisfaction, the literature says that satisfaction plays a predominant role in obtaining customer loyalty (Heskett, Sasser and Schlesinger, 1997; Gassenheimer, Houston, and Davis, 1998; Oliver, 1999; Spiteri and Dion, 2004), though the existence of satisfaction in the relationship between supplier and customer does not necessarily mean that loyalty exists (Oliver, 1999; Narayandas, 2005). For this it is necessary to be able to establish a deep and constant relationship with customers, and thus knowing them, to be able to adapt swiftly and effectively to their preferences and real values to generate a future commitment between the parties. The existence of the relationship between satisfaction, perceived value and loyalty is demonstrated by authors such as Eggert and Ulaga (2002) who analyzed the relationships between industrial suppliers and manufacturers in an inter-sector study in Germany, and determined that the direction of 
causality starts with perceived value, passes through overall satisfaction, and ends in loyalty. However, their research considers perceived value only from a cognitive and economic viewpoint, and not from a wider viewpoint as is the aim of this study, through the introduction of emotional and social aspects. Also, for Spiteri and Dion (2004), perceived value is an antecedent of overall satisfaction and of the loyalty of end customers, but they were only able to show this for a retail intensive industry: the veterinary pharmaceutical sector.

In this sense, industrial firms focus their interest on adapting their products and services to the requirements of their customers, in order to achieve their complete satisfaction through the utility obtained from their use, and with the results of it (Lapierre, 2000). And also on the creation of positive perceived value in the customer firm as a complement to satisfaction (Eggert and Ulaga, 2002).

It is also important to consider that perceived value in the three dimensions analyzed here has an important effect on satisfaction and loyalty, and that this influence does not come fundamentally from the functional facet (cognitive factors) but also from the emotional (interpersonal relations) and social facets (social image and reputation). Oliver (1999) says "ultimate loyalty is supported by the convergence of product, personal and social forces". In a cluster, personal marketing tools are fundamental, according to contributions by authors such as Lapierre (2000) for whom the image or the reputation of a firm is a key element in the decision making of its clients. It also affects their desire to remain in the relationship. Also for authors like Eggert and Ulaga (2002) for whom the personal relationships between firms' employees and managers played an important role in the generation of higher perceived value in the relationships between their firms and in achieving final loyalty. In similar terms are expressed authors as Prahalad and Ramaswamy (2004) and Vargo and Lusch (2004).

Concerning to the relationship between satisfaction and loyalty, although there are some authors who consider this relationship nonlineal (Mittal and Kamakura, 2001; Mittal and 
Niraj, 2007) due to the intensity of satisfaction depends on the moment of time and on the different situations and needs. In our research we have adopted the view of Oliver (1999) and Bennett, Härtel and McColl-Kennedy (2005) who only consider the relationship between overall satisfaction and loyalty, and how the first one affects the second one.

As a consequence of all the above, the following hypotheses can be put forward:

\footnotetext{
$\mathrm{H}_{5}$ : In a cluster, the value perceived by the customer directly and positively influences the customer's satisfaction with the supplier.

$\mathrm{H}_{6}$ : In a cluster, high indices of the customer's satisfaction with the supplier directly and positively affect the customer's loyalty to the supplier.
$\mathrm{H}_{7}$ : In a cluster, the value perceived by the customer directly and positively influences the customer's loyalty to the supplier.

\section{THE NUMBER OF SUPPLIERS AS A MODERATING VARIABLE}

The IMP Group's interactive model highlights, together with the interactive process, the importance of the atmosphere in which the relationship develops. The atmosphere of the relationship can be described in terms of balance of power-dependence, of conflictcooperation and of closeness-distance of the relationship and of expectations (Hakannson, 1982). According to the interactive model, the atmosphere can affect the relationship through an economic dimension (reducing costs) and a control dimension (reducing uncertainty). The atmosphere is therefore a moderating variable of the relationship, since it can influence the relationships posited in the model.

Moderating variables are those that influence the relationship between the independent variable and the dependent variable, and cause the level of the dependent variable to be subordinated to the fit between the moderating variable and the independent variable (Sharma, Durand and Guy-Aire, 1981; Flor and Oltra, 2002).

The number of suppliers can be considered an indicator of the atmosphere of the relationship. When a firm works with a small number of suppliers its dependence is greater, so its power position is weaker. Likewise, an industrial customer who works with a small number of 
suppliers will have a closer and more intense relationship with each supplier than one who works with a large number of suppliers. According to the IMP Group, this can lead to a lower economic cost, affecting the sacrifices component of perceived value, and to reduced uncertainty, affecting the emotional component of the value perceived by the customer. These two effects will imply higher perceived value and, following the model put forward in the paper, greater loyalty or commitment on the part of the customer.

Some studies support this hypothesis. For authors like Biong, Wathne and Parvatiyar (1997), Knox (2000), Kauffman and Leszczyc (2005) and Moeller, Fassnacht and Klose (2006), the existence of a larger or smaller number of suppliers affects both the service offered and the relationship between the parties involved. The number of suppliers affects the relationships between them and their manufacturing customers, especially for products of a certain level of sophistication. In this case, the establishment of relationships between the parties is conditioned by the intensity of the relationship necessary for the use or consumption of the product or service to occur in the established conditions, limiting the number of relationships and therefore of the individuals intervening in them (Biong, Wathne and Parvatiyar, 1997; Kim and Michell, 1999 Bowman and Narayandas, 2004). From this perspective, we put forward a new hypothesis relating to the moderating effect of the number of suppliers on the relationships between perceived value, satisfaction and loyalty.

$\mathrm{H}_{8}$ : The relationships between perceived value, satisfaction and loyalty are more intense when there are few suppliers than when there are many.

\section{METHODOLOGY}

To test the hypotheses put forward, the Spanish tile cluster was chosen. A cluster is a specific environment that conditions relationships. The aspects highlighted in the interactive model that justify the influence of the environment over the interactive process are the structure of the market, dynamism, internationalization, the position in the manufacturing channel and the social system. This Spanish tile cluster is very dynamic. It is characterized by substantial 
investment in high technology both in the process of production and in the product itself. The Spanish ceramic tile cluster is the second largest producer in the world, with a high degree of internationalization since it exports more than half its production to 180 countries. Manufacturers need close contact with their suppliers, especially makers of frits ${ }^{1}$, enamels, and ceramic colors, because they affect the design of the final product. This is the most important reason for interviewing purchasing managers about the manufacturing firm's relationship with its main supplier of frits, enamels and ceramic colors.

The justification of the choice of this type of supplier is that, among the variety of firms, possibly the regularity of deliveries, together with the technical knowledge of the product, requires a greater quantity and quality of contacts. The relationship between the manufacturer and the supplier of frits, enamels and ceramic colors is a long term one. The nearness of other competing suppliers means that loyalty is threatened because these firms are continually innovating and creating value for the customer (Plank and Newell, 2006). Together with this, because of the geographical concentration, there exist personal links with other competitors that make it easy to change supplier, and the costs of transport are considerably reduced. The study of customer loyalty and its antecedents will therefore enable us to find the keys to the success of long term relationships in this context.

The information was gathered by the method of self-administered survey. For designing the scales of measurement of the questionnaire, in the first one we used secondary information sources in order to obtain the information necessary to be able to develop suitable scales of measurement. We consulted different studies by different authors (Anderson and Weitz, 1992; Morgan and Hunt, 1994; Gundlach Achrol and Mentzer, 1995; Lusch and Brown, 1996; Sweeney, Soutar and Jonson, 1999; Lapierre, 2000; Wetzels, De Ruyter and Van Birgelen, 1998; Jap and Ganesan, 2000; Sweeney and Soutar, 2001; Eggert and Ulaga, 2002).

\footnotetext{
${ }^{I}$ frits are vitreous compounds, insoluble in water, made by melting at high temperature $\left(1500^{\circ} \mathrm{C}\right)$ followed by fast cooling of the raw materials mixture. Most of the glaze compositions used in tile manufacture has a larger or smaller fritted part, which can consist of a single frit or blend of different types of frits.
} 
Nevertheless, given the shortage of studies focused on perceived value in the industrial market, in order to adapt the content to the industry analyzed, we also carried out a pre-test with 5 purchasing managers, who representing $5 \%$ of the sample. Pre-test participants were in fact representative, i.e. selected from the target population. Before the questions were administered, participants were informed about the pre-test, and their cooperation was requested in spotting words, phrases, instructions, question flow, or other aspects of the questionnaire that might appear confusing, difficult to understand or otherwise a problem. In this pre-test we rewrote those questions that seemed unclear, without changing the essence of the original scales proposed on the basis of the bibliographical review. We also added questions that the purchasing managers considered important in their activity, e.g. items VF21 (Security (VF21): "For our firm the technical advice offered by the supplier for the management of our business is very important") and VF29 (Monetary Sacrifice (VF29): “The price offered is influenced by market competition"). In this way, the scales were designed specifically for the objectives of the study, on the basis of a first bibliographical review.

Once the pretest had been carried out, the definitive questionnaire was obtained to carry out the quantitative study. This questionnaire was structured in seven major sections, following the scheme: functional value technical quality of the product, functional value quality of service, functional value sacrifices, social value and emotional value, satisfaction and loyalty (table 1).

\section{TABLE 1}

According to the aims of the study, the method of information gathering chosen was a survey, addressed to the purchasing manager of the firm or by default to the managing director of the ceramic tile manufacturing firm. It was carried out in three successive phases: first it was sent by post, together with a letter of presentation of the study and its motives. To reinforce this, reception of the questionnaire, and the willingness of the receiver to respond, was checked by 
telephone, permitting a second sending, in this case by e-mail. Despite this, in both cases very few responses were obtained, obliging us, in a third phase, to carry out personal interviews with those firms that did not reply in the earlier phases. Once an appointment had been made, an interviewer traveled to the firm's head office and administered the questionnaire by means of a personal interview with the purchasing manager. This last phase was favored by the geographical concentration of the firms in the province of Castellón (Spain).

The population consists of all firms of the Spanish ceramic tile industry (245 firms, manufacturers of paving and wall tiles, and special pieces). Twenty-five (25) firms are suppliers of frits, enamels and ceramic colors.

The sample obtained consisted of 101 observations $(41.2 \%$ of the whole), which for a confidence level of $95.5 \%(\mathrm{z}=2)$, and for an estimation of proportions of $(\mathrm{p}=\mathrm{q}=0.5)$, gives a sample error of $\pm 7.84 \%$.

The models were tested with Structural Equation Models (SEM). Confirmatory factor analysis (CFA) is the most suitable for the purposes of this study, as we aim to confirm a series of hypotheses based on the bibliographical review and shown in the conceptual model in Figure 1. In all the causal models obtained in the course of the data analysis the maximum likelihood estimation method (Jöreskog and Sörbom, 1989, 1996b) is applied, taking as reference the variance-covariance matrix calculated from the normalized data after application of the normal scores procedure offered by PRELIS, which permits the joint normalization of the continuous variables being analyzed (Jöreskog and Sörbom, 1996a). Moreover, in all these models the parameters that determine the relationships between the variables are always significant, the associated $t$ value being higher than 1.96 , and are completely standardized.

\section{RESULTS}

The analysis of the data starts with a study of the dimensions, reliability and validity of the scales used, by means of confirmatory factor analysis. Next a second order confirmatory 
factor analysis was carried out in order to determine the importance of each dimension. Appendix gives tables 11 to 13 with all the items used to draw up the scale of measurement. Finally a path analysis was performed to permit us to determine the relationships among the variables analyzed.

\subsection{Dimensions, reliability and validity of the scales of measurement of perceived value}

The hypothesis made in respect of functional value establishes the existence of components of sacrifices and of benefits. The bibliographical review has enabled us to identify in turn three dimensions relating to quality in the positive component (product quality, the firm's service quality and the employees' service quality). Together with these positive functional dimensions we identify one negative functional dimension, one emotional dimension and one social dimension.

As already remarked, a confirmatory factor analysis was carried out to determine the dimensions, reliability and validity of the scale of measurement of the functional value product quality (table 2). This analysis shows the existence of two sub-dimensions: durable quality and technical quality. In the case of the durable quality of the product, the highest factor loading is associated with the fact that the reliability of the products purchased increases with the passage of time (0.77). For the technical quality of the product, the highest factor loadings are associated with the suitability of the technical specifications of the supplier's products and with the fact that the supplier firm offers the best products; both factor loadings take the value 0.64 .

\section{TABLE 2}

Table 3 shows the individual analyses of the dimension firm's service quality. In it can be distinguished three sub-dimensions. On the one hand tangibility-technical competence, whose items with highest factor loading have 0.83 corresponding in this case to creativity and innovation in products and services; the main supplier's expertise and application of new 
technologies for the solution of problems. The second sub-dimension detected is reliability. In this case as well, various items appear with the same factor loading as above (0.83), and refer to speed and agility; fulfillment of dates and services promised, and doing things well the first time. Finally, the factors detected in the sub-dimension security (accuracy of information, fulfillment of promises and technical advice) present factor loadings lower than the above.

\section{TABLE 3}

In the analysis of reliability and validity of the scale used to measure the employees' quality

of service (table 4) it can be appreciated that the two items with highest factor loading (both with 0.92 ) are those referring to the employees' reliability and consistency, and competence and professionalism, respectively.

\section{TABLE 4}

From the factor analysis carried out for total sacrifices we obtain three sub-dimensions (table 5): the first refers to monetary sacrifices, the second to the non-monetary sacrifice of convenience, and the third to the non-monetary sacrifice costs of change. In the first subdimension the highest factor loadings are related to the items perception of a reasonable price, and the offer of the best discounts and payment conditions. The factor loading being 0.80 in both cases.

\section{TABLE 5}

In the case of the convenience sub-dimension, the highest factor loading is related to the importance of the number of visits made (0.65). The two items that form the dimension costs of change have similar factor loadings ( 0.69 and 0.68 respectively); these items refer to the effort and time that would be involved in changing supplier, and to the importance of continuing the relationship with the supplier.

Social value (table 6) presents two sub-dimensions, social image and reputation. In the former, the two items with highest factor loadings are the external recognition of its social 
behavior (0.83) and internal ethical behavior (0.81). For the social reputation of the supplier firm, the item with highest factor loading (0.92) refers to the supplier's credibility and its positive effect on the social image of the firm.

\section{TABLE 6}

Three sub-dimensions of emotional value have been detected: experience, affective relationships, and personalized relationships or attention. The confirmatory factor analysis of all its components (table 7) shows that for the experience sub-dimension the items with highest factor loadings are the ease of use of the products/services $(0.72)$ and the perception of the supplier as an expert (0.70). Personalized attention, physical recognition and remembering the customer's name present the same factor loading (0.70). Finally, in interpersonal relationships we find the item with highest factor loading, which refers to the pleasantness of dealings with the employees of the supplier firm (0.74), followed by general pleasantness in dealings with the supplier (0.70) and the development of bonds of friendship between the workers of the two firms $(0.70)$.

\section{TABLE 7}

Therefore, in respect of the study of the dimensions, reliability and validity of the scale of measurement of perceived value, all the analyses performed in this section are adequate, since the probability associated with the chi squared is greater than 0.05 , the statistics GFI and AGFI are close to unity; and RMSEA close to zero (Hair, Anderson, Tatham and Black, 1999).

Furthermore, the scales used are all reliable, as the coefficient of composite reliability is always higher than 0.63, and reaches values higher than 0.95 (Bagozzi and Yi, 1988). The convergent validity of the scales is also ratified, the factor loadings being always higher than 0.5; and because each item contributes to the formation of only one factor (Bagozzi and Yi, 1988; Bagozzi, Yi and Phillips, 1991; Steemkamp and Trijp, 1991). The divergent validity of 
the scales is confirmed because the confidence interval of the correlation between the dimensions obtained does not include unity (Bagozzi and Yi, 1988; Steemkamp and Trijp, 1991).

\section{TABLE 8}

Having performed the above confirmatory factor analyses for each one of the components of the value perceived by the firm, we proceed to a confirmatory factor analysis of the whole. We start from the weighted mean values obtained from the previous analyses. In table 8 , it can be appreciated that the results obtained in the previous analyses are corroborated, obtaining a model with good fit and a reliable scale with both convergent and divergent validity, following the criteria indicated at the start of the data analysis.

As we observe, functional value is made up, in order of importance of the factor loadings, of the overall quality of the firm's service (0.84); of the quality of its employees' service (0.76); of the overall quality of the product (0.76); of convenience (0.69); of the price (0.62); and of the costs of change (0.54). $\mathrm{H}_{2}$ is thus fulfilled. Emotional value, for its part, is made up of experience (0.89); interpersonal relationships (0.80); and personalized attention (0.58). Hypothesis $\mathrm{H}_{3}$ is thus empirically demonstrated. And, finally, social value is formed by social image and reputation, both with the same explanatory factor loading (0.75). Hypothesis $\mathrm{H}_{4}$ is also fulfilled in this case.

The analysis of discriminant validity shows that the three variables are correlated, which indicates the importance of all of them in the management of perceived value in relationships with the industrial supplier (Gwinner, Gremler and Bitner, 1998; Sweeney and Soutar, 2001). The correlation between emotional value and functional value stands out among them, with a value of 0.69 .

Continuing with the overall analysis of total perceived value, a second order factor analysis is carried out, in which weighted measurements are made and a variable is calculated to capture 
the overall value, which is what will be introduced into the general model. This analysis is undertaken in order to obtain an overall latent variable for total perceived value. The results of this second order confirmatory factor analysis are shown in figure 2, where we can observe that three first order factors are obtained which include the same items as those obtained in the above analyses, determining that for each one of these factors the factor loadings maintain similar proportions to those considered individually above.

\section{FIGURE 2}

A second order factor is also obtained, to capture total perceived value. This factor is formed by functional value $(0.91)$, emotional value $(0.95)$, and social value $(0.94)$. It is worth highlighting, in interpreting the results, that although all three have a high factor loading, emotional value has the highest explanatory capacity in the formation of the overall value perceived by the customer firm, though by only a slight difference. Nevertheless, the close equality among them determines the need to consider them as a whole for the correct interpretation of customer perceived value, as posited by Sweeney and Soutar (2001). That is to say that perceived value is shown to be a multidimensional construct in which the three dimensions interact and complement each other, in a balanced way, and help us to understand a complex construct that adopts different roles and may be interpreted in different ways by customers, as manifested by authors such as Sheth, Newman and Gross (1991a), De Chernatony, Harris and Dall'Olmo (2000) and Sweeney and Soutar (2001).

The resulting model is adequate, as the probability associated with chi squared is greater than 0.05 (0.052); the statistics GFI (0.86) and AGFI (0.84) are close to unity; and RMSEA (0.057) close to zero (Hair, Anderson, Tatham and Black, 1999). Reliability is high both for the first order factors and for the second order factor, the overall reliability of total perceived value being 0.9538 (Bagozzi and $\mathrm{Yi}, 1988$ ). It has convergent validity, as all the factor loadings are above 0.5 ; and also divergent validity for each of the dimensions of total perceived value, 
since the items that constitute them form part of this factor only and do not contribute to forming any other factor (Bagozzi and Yi, 1988; Bagozzi, Yi and Phillips, 1991; Steemkamp and Trijp, 1991).

Altogether, in this case too $\mathrm{H}_{1}$ is fulfilled, and the value of a relationship as perceived by a customer firm is empirically demonstrated to be constituted by a functional dimension, an emotional one and a social one, reinforcing affirmations made in this sense by Sweeney and Soutar (2001).

\subsection{Analysis of dimensions, reliability and validity of the scale of loyalty}

In the analysis of the dimensions of the items used to measure the loyalty variable in interorganizational relationships, after performing the confirmatory factor analysis, we obtain a single factor (table 9).

\section{TABLE 9}

As we can observe, in the formation of latent loyalty or the manufacturer's future behavior intentions towards its supplier, future intentions of permanence and recommendations contribute with the same factor loading (0.82), indicating that both have the same explanatory capacity with regard to the loyalty variable. In this case the item LEAL3 "We prefer to pay a little more in exchange for the benefits offered by our supplier" does not enter into the model, as the confirmatory factor analysis has caused it to be eliminated, because the degree of correlation between this item and the rest of the errors was very high (Jöreskog and Sörbom, 1989, 1996a, 1996b).

Also in this case, the resulting model is sustainable, because the probability associated with chi squared is greater than 0.05 (0.80305); The statistics GFI (0.99) and AGFI (0.99) are very close to unity; and RMSEA (0.001) very close to zero (Hair, Anderson, Tatham and Black, 1999). The scale is also reliable because the coefficient of composite reliability is 0.8030 (Bagozzi and Yi, 1988). It possesses convergent validity because all factor loadings are 
greater than 0.5 ; and also divergent validity for each of the dimensions of loyalty, because the items that form each of them only form part of that one and do not contribute to the formation of any other factor (Bagozzi and Yi, 1988; Steemkamp and Trijp, 1991).

\subsection{Testing of the overall model}

With the type of scales used in this study, we obtain similar results when applying structural equations models with latent variables, as when applying path analysis on the basis of the mean values of the items constituting the latent variables (Sánchez and Moliner, 2002). Furthermore, in all these models the parameters that determine the relationships between the variables are always significant, their associated t values being greater than 1.96 (Jöreskog and Sörbom, 1989, 1996a, 1996b).

In this way, taking as reference the mean values weighted according to the factor loadings obtained in the previous analyses, a path analysis will be performed to test hypotheses H5, H6, H7 and H8, which establish the causal relationships between the variables being analyzed. In these hypotheses, we consider the number of suppliers as a moderating variable. We establish two groups according to the median: on the one hand when the firm has 5 or more suppliers, and on the other hand, when the firm has 4 or less suppliers.

\section{FIGURE 3}

First we analyze the overall model, and as can be observed in figure 3, the resulting model is sustainable according to the postulates of Hair, Anderson, Tatham and Black (1999), as the probability associated with chi squared is greater than 0.05 (0.61237); the statistics GFI (0.99) and AGFI (0.99) are very close to unity; and RMSEA (0.001) close to zero. Overall perceived value directly influences satisfaction (0.64) and loyalty (0.44) and also indirectly influences the latter through satisfaction. Satisfaction for its part directly influences loyalty (0.29). These results determine that hypotheses $\mathrm{H} 5, \mathrm{H} 6$ and $\mathrm{H} 7$ are fulfilled. 
Regarding the action of the variable "number of suppliers" on the model, the sample is divided into two sub-samples according to whether the tile manufacturing firms have 5 or more suppliers $(n=65)$, or less than $5(n=36)$. The results obtained in the first case indicate that the resultant model and the causal relationships indicate that value directly influences satisfaction (0.46) and loyalty (0.46) and influences loyalty indirectly through satisfaction. Satisfaction, for its part, influences loyalty (0.20).

\section{FIGURE 4}

For the case of firms with fewer than 5 suppliers, the causal relationships obtained indicate that value also influences satisfaction (0.74) and loyalty (0.56) directly, and loyalty indirectly through satisfaction. Satisfaction also has a positive influence on loyalty (0.27).

An overall comparison of the two models shows that there are no significant differences between one and the other, as the probability associated with chi squared is 0.42087 (greater than 0.05$)$. The relationships have also been compared one by one, finding no significant differences in any of the three cases, as the probability associated with chi squared is always greater than 0.05 (table 10).

\section{TABLE 10}

\section{CONCLUSIONS}

\subsection{Theoretical contributions}

This study has permitted a deeper understanding of the loyalty behavior of a customer in the setting of a cluster. The theoretical framework of the study has been that of relationship marketing, though the contributions of the IMP Group's interactive model have also been taken into account. This paper makes a small contribution to the integration of the two points of view (Plank and Newell, 2005). Relationship Marketing studies the maintenance of long term relationships beneficial to both parties. Its proposals have arisen in recent years as an alternative vision to the proposals of the IMP Group's interactive model. Nevertheless the two 
visions can be complementary if an open view is adopted. The proposed model of customer loyalty offers an explanation of the IMP Group's interactive process, in which four types of short term exchange episodes (product/service, information, financial and social) and two long term relationships (institutionalization and adaptations) are posited. From the customer's perspective, the four social exchanges are included in the perceived value, while the long term consequences can be considered specific behaviors resulting from the customer's loyalty or commitment to a particular supplier. In this sense, the model presented enables the behavior of the industrial customer to be better understood.

Together with this, the environment (cluster) and the atmosphere (number of suppliers) of the interactive model have been taken into account, and incorporated into the relationship marketing approach. The two approaches can therefore be complementary.

The results of the empirical study show that in the context of a cluster, perceived value and satisfaction are antecedents of customer loyalty. More specifically, perceived value, from a multidimensional perspective, is identified as the key variable in the formation of satisfaction and of customer loyalty. This shows, or at least helps to understand better, the central role that the AMA (2004) assigns to perceived value. For the maintenance of long term relationships it is therefore fundamental to pay attention to perceived value and its different components.

This paper also demonstrates the importance of the emotional and social dimensions, at a similar level to the functional dimension of perceived value. The traditional literature on industrial marketing emphasized the importance of the functional aspects of the product in the decision to purchase or to re-purchase. In this point there is an important parallel with the proposal of the IMP Group, who also considered a social component which has a certain correspondence to the emotional value in this study.

This article highlight the role played by interpersonal relationships, and by the image projected, in the overall valuation that a customer makes of its suppliers. The results of the 
empirical research in a cluster have shown the importance of emotional and social value in the formation of the overall value of the relationship perceived by the customer firm. Undoubtedly, the fact that firms consist of people notably influences the existence of emotions, sentiments, feelings and sensations that affect the final decisions of the people with decision-making capacity in firms (Andersen and Kumar, 2006). Also, the notable increase in the importance of the social perception of the firm and of its influence on economic results, has led to social value also playing a more than significant role in the perception of higher value by the industrial purchaser. With regard to social value, the results of the study show that in its two dimensions considered, social image and reputation, the factors most valued by the customer firm are good social practices and credibility in general. In this situation the proper management of information becomes a key factor in business and social success (Nguyen and Leblanc, 2001). If the results of the investigation show that firms' customers are sensitive to the social behavior of the supplier firm, but at the same time its credibility is high, in this situation it is important for the firm to be able to communicate internally and externally all its achievements in this direction.

Finally, we have analyzed the influence that a moderating variable such as the number of suppliers may have on the model (as an indicator of the atmosphere in which the relationship develops). The results show that the number of suppliers does not affect the relationships between manufacturing firms and the suppliers of frits enamels and colors, which partly contradicts some of the theoretical considerations that existed in this respect in the literature on channel relationships. Thus, neither the conditions of power-dependence nor those of nearness-distance affect customer loyalty.

\section{Implications for Business Marketing Practice}

The main business implication is that, in a cluster, in order to achieve long term relationships with a customer, and therefore his loyalty and commitment, it is necessary to implement a 
strategy of creation, distribution and communication of value in all senses. In view of the identification of the emotional and social components in the decision-making of the firms in a cluster, and in the formation of the value perceived by the customer, the managers of supplier firms should reconsider the need to develop a commercial policy in harmony with a social and human policy. The need to train personnel with the triple perspective proposed in the dimensions of perceived value will be of great importance in the near future, judging by the results of the empirical study.

In a way, the presence of the emotional and social component in customer perceived value is linked to the conception of relationship marketing as a humanized form of marketing. In this context, commercial strategies based on intensive production processes, based in turn on the application of mass marketing, must give way to marketing with a more individualized application. For this it must be based on research and the proper use of data bases, the application of which permits personalized treatment, i.e. offering products and services in the conditions required by the customers. The results of the study reveal that emotional and social aspects within a cluster have a notable influence on such decision making. This is due principally to the necessary conjugation of the dual aim of firms, objectives of an economic and business nature and of a human and personal nature. The fact that firms are formed basically of people endows them with features and characteristics that make each one different from the other, and evidently conditions their final valuation in decisions to purchase from one supplier or another. It is therefore important to consider and monitor, along with functional value, the introduction of emotional and social factors.

This, moreover, represents a barrier to entry by suppliers located outside the cluster. In this case, for a supplier not located in the cluster to be able to compete on equal terms with the suppliers already installed, it will be fundamental to establish a base within the cluster. In this way he will begin to establish personal relationships that generate emotional and social value. 
This is in fact the strategy followed by the Spanish makers of frits, enamels and ceramic colors, in their international growing, which have installed production plants in the Italian, Chinese, Brazilian and Mexican ceramic clusters, among others, becoming the world leaders. The supplier firms in a cluster, therefore, must be capable of working in these three directions. At least the employees whose functions require them to interact with customer firms must be given training in this perspective. On the one hand, technical training concerning the product and the services that the firm offers. Technical characteristics of use, installation and operation, among others, must be known by them. On the other hand, they must be endowed with human training, understood as skills for the development of interpersonal relationships, of social sensitivity, of respect towards people and of integration in a working group. And they must also be trained to be sensitive to environmental matters and business ethics, how a negative image in these aspects can affect the firm externally, and how to work to improve it constantly. And finally, specific training in their work speciality. To the studies and experience that the person brings to the job, must be added continuous training in order to be able to incorporate and understand the new advances that are continually occurring in each field. Finally, a thorough knowledge of the firm, its vision, mission, culture and values, enables them to conceptualize all this knowledge in the area where they have to develop it.

A number of limitations should be taken into account when extrapolating the results. First, the lack of significant differences between the two models formed on the basis of the moderating variable may be due to the size of the sample, as it is well known that the Lisrel analysis punishes small samples.

A second limitation that deserves to be highlighted is that we have studied a very specific case of relationships in a cluster. In the empirical study, moreover, we only asked the firms interviewed for a valuation of their main industrial supplier. 
In order to advance in this line of research, this study should be developed in other clusters that would allow better integration of more diverse business cultures or philosophies.

A future line of research could be to expand the proposed model and to incorporate new variables such as trust. Trust and commitment are considered to be important elements in the maintenance of long term relationships (Morgan and Hunt, 1994). In this study we have adopted the view of Oliver (1999) and Bennett, Härtel and McColl-Kennedy (2005) who consider that loyalty and commitment are two sides of the same coin. Nevertheless, it would be necessary to incorporate trust in order to analyze the role of this variable in the formation of the loyalty of an industrial customer in a cluster, also studying how perceived value and satisfaction influence trust.

We even consider necessary to outline the nonlinear relationship between satisfaction and loyalty, in the sense indicates by authors as Mittal and Kamakura, (2001) and Mittal and Niraj (2007).

Another aspect to be analyzed in the future is the influence of loyalty, understood as attitude or commitment, and the specific behaviors of the customer. A first element of study would be to analyze how customer loyalty influences the long term relationships (institutionalization and adaptations) highlighted in the IMP Group's interactive model. In principle greater customer loyalty should help to explain the institutionalization of expectations and higher levels of adaptation and cooperation. In this line, it would also be crucial to study the influence of customer loyalty on the seller's results, such as sales and profits, and whether more loyal customers means more profitable customers, as posited by relationship marketing. Likewise it would be interesting to analyze how loyalty influences the customer's price sensitivity and his complaints behaviors.

Finally, there is feedback, in the sense that customer loyalty can influence perceived value and customer satisfaction. This is therefore a dynamic model whose testing with time series 
Customer loyalty in clusters: perceived value and satisfaction as antecedents

would be of great help in understanding the dynamics of long term relationships in industrial markets. 


\section{References}

Allee, V., The Value Evolution, Journal of Intellectual Capital 1, 1, 17-32 (2000)

American Marketing Association (AMA), available at http://www.marketingpower.com/mgdictionary-view1862.php (2004)

Andaleeb, S.S., An Experimental Investigation of Satisfaction and Commitment in Marketing Channels: The Role of Trust and Dependence, Journal of Retailing 72, 1, 77-93 (1996)

Andersen, P.H. and Kumar, R., Emotions, Trust and Relationships in Business Relationships: A Conceptual Model for Buyer-Seller Dyads, Industrial Marketing Management 35, 4, 522-535 (2006)

Anderson, J.C., Relationships in Business Markets: Exchange Episodes, Value Creation and their Empirical Assessment, Journal of the Academy of Marketing Science 23, 4, 346350 (1995)

Anderson, J.C.; Jain, D.C. and Chintagunta, P.K., Customer Value Assessment in Business Markets: A State-of-Practice Study, Journal of Business to Business Marketing 1, 1, 330 (1993)

Anderson, J.C. and Narus, J.A., A Model of The Distributor's Perspective of DistributorManufacturer Working Relationships, Journal of Marketing 48, 62-74 (1984)

Anderson, J.C. and Narus, J.A., Business Market Management: Understanding, Creating and Delivering Value, 2d. ed. Upper Saddle River, NJ: Pearson/Prentice Hall, 2004

Anderson, J.C. and Weitz, B., The Use of Pledges to Build and Sustain Commitment in distribution Channels, Journal of Marketing Research, February, 18-54 (1992)

Bagozzi, R.P. and Yi, Y., On the Evaluation of Structural Equation Models. Journal of the Academy of Marketing Science 16, 1, 74-94 (1988)

Bagozzi, R.P.; Yi, Y. and Phillips, L.W., Assessing construct validity in organizational research, Administrative Science Quarterly 36, 421-458 (1991)

Bagozzi, R.P. Gopinath, M. and Nyer, P.U., The Role of Emotions in Marketing. Journal of the Academy of Marketing Science 27, 2, 184-206 (1999)

Bennett, R., Härtel, Ch., and McColl-Kennedy, J.R., Experience as a moderator of involvement and satisfaction on Brand Royalty in a Business-to Business Setting 02314R, Industrial Marketing Management 34, 1, 97-107 (2005)

Berry, L.L.; Seider, K. and Gresham, L.G., Understanding Service Convenience, Journal of Marketing 66, 1-17 (2002)

Biong, H., Wathne, K. and Parvatiyar, A., Why do some Companies not Want to Engage in Partnering Relationships, in Relationships and Networks in International Markets, Hans Georg Gemünden, Thomas Ritter and Achim Walter, eds., Elsevier, Oxford (1997) 
Bonner, J.M. and Calantote, R.J., Buyer Attentiveness in Buyer-Seller Relationships, Industrial Marketing Management 34, 1, 53-61 (2005)

Bowman, D. and Narayandas, D., "Linking Customer Management Effort to Customer Profitability in Business Markets", Journal of Marketing Research, 41, 4, 433-447, (2004)

Brennan, D. R.; Turnbull, P.W. and Wilson, D.T., Dyadic Adaptation in Business-to-Business Markets, European Journal of Marketing 37, 11/12, 1636-1665 (2003)

Brown, J.R.; Lusch, R.F. and Nicholson, C.Y., Power and Relationship Commitment: Their Impact on Marketing Channel Member Performance, Journal of Retailing 74, 4, 363 392 (1995)

Cannon, J.P. and Perreault Jr, W.D., Buyer-Seller Relationships in Business Markets, Journal of Marketing Research, 36, 4, 439-460 (1999)

Christopher, M.; Payne, A. and Ballantyne, D., Relationship Marketing: A stakeholder value perspective, Butterworth-Heinemann, Oxford (2002).

Cronin Jr, J.; Brady, M; Brand, R.R.; Hightower Jr, R. and Shemwell, D.J., A Cross-sectional Test of the Effect and Conceptualization of Service Value, The Journal of Services Marketing 11, 6, 375-218 (1997)

Cronin Jr, J.; Brady, M. and Hult, T., Assessing the Effects of Quality, Value, and Customer Satisfaction on consumer Behavioral Intentions in Service Environments, Journal of Retailing 76, 2, 193-218 (2000)

De Chernatony; L.; Harris, F. and Dall'Olmo Riley, F., Added Value: Its Nature, Roles and Sustainability, European Journal of Marketing 34, 1-2, 39-56 (2000)

De Ruyter, J.K.; Wetzels, M.; Lemmink, J. and Mattson J., The Dynamics of the Service Delivery Process: A Value-Based Approach, International Journal of Research in Marketing 14, 231-243 (1997)

De Ruyter, J. K, Wetzels, M. and Bloemer, J., On the Relationship Perceived Service Quality, Service Loyalty and Switching Costs, International Journal of Service Industry Management 9, 5, 436-453 (1998)

Dick, A and Basu, K., Customer Loyalty: Toward an Integrated Conceptual Framework, Journal of Academy of Marketing Science 22, 2, 99-113 (1994)

Diller, H., Customer Loyalty as a Marketing Objective, Marketing ZFP 18, 2, 81-94 (1996); in Henning-Thurau, Th. and Hansen, U., Relationship Marketing: Gaining Competitive Advantages Through Customer Satisfaction and Customer Retention, Springer-Verlag Berlin Heidelberg (2000)

Dodds, W.B: Monroe, K.B. and Grewal, D., Effects of Price, Brand and Store Information on Buyers' Product Evaluations, Journal of Marketing Research 28, 307-319 (1991) 
Eggert, A and Ulaga, W., Customer Perceived Value: A Substitute for Satisfaction in Business Markets?, Journal of Business and Industrial Marketing 17, 2/3, 107-118 (2002)

Eggert, A., Ulaga W. and Schultz F., Value creation in the relationship life cycle: a quasilongitudinal analysis, Industrial Marketing Management 35, 20-27 (2006)

Emiliani, M.L., Sourcing in the Global Aerospace Supply Chain using Online Reverse Auctions, Industrial Marketing Management 33, 65-72 (2004)

Eriksson, K., Majkgard, A. and Sharma, D.D., Service Quality by Relationships in the International Market, Journal of Services Marketing 13, 4/5, 361-375 (1999)

Flint, J. D. and Woodruff, R.B., The Initiators of Changes in Customer's Desired Value: Results from a Theory Building Study, Industrial Marketing Management 30, 321-337 (2001)

Flint, J. D., Woodruff, R.B. and Gardial, S.F., Exploring the Phenomenon of Customers' Desired Value Change in a Business to Business Context, Journal of Marketing 66, 4 (2002)

Flor, M.L. and Oltra, M.J., Tratamiento metodológico de variables moderadoras mediante efectos de interacción: aplicación a la relación estratégica de innovación-desempeño internacional, in English, Methodological Treatment of Moderating Variables by Means of Effects of Interaction: an Application to the Strategic Relation of International Innovation-Performance, Proceedings VIII Taller de Metodología ACEDE, Benicassim (Castellón), May 16-17th (2002)

Ford, D., The Development of Buyer-Seller Relationships in Industrial Markets, European Journal of Marketing 14,5, 339-354 (1980)

Ford, D., Hakannson, H., and Johanson, J., How do Companies Interact?, Industrial Marketing \& and Purchasing 1, 26-41 (1986)

Frazier, G.L., Gill, J.D. and Sudhir H.K., Dealer Dependence Levels and Reciprocal Actions in a Channel of Distribution in a Developing Country, Journal of Marketing 53, 50-69 (1989)

Ganesan, S., Determinants of Long-Term Orientation in Buyer-Seller Orientation in BuyerSeller Relationships, Journal of Marketing 58, 1-19 (1994)

Ganesan, S., Malter, A:J. and Rindfleisch, A., Does Distance Still Matter? Geographic Proximity and New Product Development, Journal of Marketing, 69 (October), 44-60 (2005)

Gardial, S.F.; Clemons, D.S.; Woodruff, R.B.; Schumann, D.W. and Burns, M.J., Comparing Consumer's Recall of Prepurchase and Postpurchase Product Evaluation Experiences, Journal of Consumer Research 20, 548-560 (1994)

Gaski, J. and Nevin, J.R., The Differential Effects of Exercised and Unexercised Power Sources in a Marketing Channel, Journal of Marketing Research 22, 130-142 (1985) 
Gassenheimer, J.B.; Houston, F.S. and Davis, J., The Role of Economic Value, Social Value and Perceptions of Fairness in Interorganizational Relationship Retention Decisions, Journal of Academy of Marketing Science 26, 4, 322-337 (1998)

Geyskens, I.; Steenkamp, J.B. and Kumar, N., A Meta-Analysis of Satisfaction in Marketing Channel Relationships, Journal of Marketing Research 26, 223-238 (1999)

Grewal D.; Monroe, K. and Krishnan, R., The Effects of Price-Comparison Advertising on Buyers' Perceptions of Acquisition Value, Transaction Value, and Behavioral Intentions, Journal of Marketing 62, 2, 46-59 (1998)

Gundlach, G.T.; Achrol, R.S. and Mentzer, J.T., The Structure of Commitment in Exchange, Journal of Marketing 59, January, 78-92 (1995)

Gwinner, K.; Gremler, G. and Bitner, M.J., Relational Benefits in Services Industries: The Consumer's Perspective, Journal of The Academy of Marketing Science 26, 2, 101$114(1998)$

Hair, J.F.; Anderson, R.E.; Tatham, R.L. and Black, W., Multivariate Data Analysis, Fifth Edition: Prentice Hall International (1999)

Hakannson, H., International Marketing and Purchasing of Industrial Goods. An Interaction Model, John Wiley and Sons (1982).

Hallen, L and Sandström, M., Relationship Atmosphere in International Business, In S. J. Paliwoda (Ed.), New Perspectives on International Marketing, London: Routledge (1991)

Heskett, J.L., Sasser Jr., W.E. and Schlesinger, L.A., The Service Profit Chain, New York, The Free Press (1997)

Holbrook, M.B. and Hirschman, E.C., The Experiential Aspects of Consumption: Consumer Fantasies, Feelings, and Fun, Journal of Consumer Research 9, 132-140 (1982)

Henning-Thurau, Th.; Gwinner, K.P. and Gremler, D. D., An Integration of Relational Benefits and Relationship Quality, Journal of Service Research 4, 3, 230-247 (2002)

Henning-Thurau, Th. and Hansen, U., Relationship Marketing: Gaining Competitive Advantage through Customer Satisfaction and Customer Retention, Journal of Consumer Marketing 18, 1, 75-83 (2001)

Hewett, K; Money, R.B. and Sharma, S., An Exploration of the Moderating Role of Buyer Corporate Culture in Industrial Buyer-Seller Relationships, Journal of the Academy of Marketing Science 30, 3, 229-239 (2002)

Hinterhuber, A., Towards value-based pricing. An integrative framework for decision making, Industrial Marketing Management 33, 8, 765- 778 (2004)

Hogan, J. E., Expected Relationship Value: A Construct, a Methodology, and a Modeling Technique, Industrial Marketing Management 30, 339-351 (2001) 
Jöreskog, K. G., and Sörbom, D., LISREL 7: A guide to the Program and Applications (2nd ed.). Chicago: SPSS (1989)

Jöreskog, K. G., and Sörbom, D., LISREL 8: User's Reference Guide. Chicago: Scientific Software (1996a)

Jöreskog, K. G., and Sörbom, D., PRELIS 2: User's Guide. Chicago: Scientific Software (1996b)

Kauffman, R. G. and Leszczyc, P.T., An Optimization Approach to Business Buyer Choice Sets: How Many Suppliers Should Be Included?, Industrial Marketing Management 34, 1, 3-12 (2005)

Kim, J-B and Michell, P., Relationship Marketing in Japan: The Buyer-Supplier Relationships of Four Automakers, Journal of Business and Industrial Marketing 14, 2, 118-129 (1999)

Klemz, B.R. and Boshoff, C., Environmental and Emotional Influences on Willingness-toBuy in Small and Large Retailers, European Journal of Marketing 35, 1-2, 70-91 (2001)

Knox, S., Organizational Buyer Behaviour, in Marketing Management. A Relationship Marketing Perspective, Cranfield School of Management eds, London (2000)

Lacoeuilhe, J., Le Concept d'Attachement a la Marque dans la Formation du Comportament de Fidelité, Revue Française du Marketing 165, 5, 29-42 (1997)

Lapierre, J., Customer-perceived Value in Industrial Context, Journal of Business \& Industrial Marketing 15, 2/3, 122-140 (2000)

LaPlaca, P.J., Letter from the Editor, Industrial Marketing Management 35, 1-3 (2006)

LaPlaca, P.J., Letter from the Editor, Special issue on customer relationship marketing, Industrial Marketing Management 33, 463-464 (2004)

Leonidou, L.C., Industrial Manufacturer-Customer Relationships: The Discriminating Role of the Buying Situation, Industrial Marketing Management 33, 1, 731-742 (2004)

Lindgreen, A. and Wynstra F., Value in Business Markets: What do we Know? Where Are We Going?, Industrial Marketing Management 34, 7, 732-748 (2005)

Lovelock, C. H., Understanding Costs and Developing Pricing Strategies. In Services Marketing: Text, Cases and Readings. Ed.. Prentice Hall International Editions, 2nd ed., 236-248 (1991)

Lusch, R.F. and Brown, J.R., Interdependency, Contracting, and Relational Behavior in Marketing Channels, Journal of Marketing 60, October, 19-38 (1996)

Metcalf, L.E., Frear, C.R. and Krishman, R., Buyer-Seller Relationships. An Application of the IMP Interaction Model, European Journal of Marketing 26, 2, 27-46 (1992) 
Mittal, V., and Kamakura, A.W., Satisfaction, Repurchase Intent, and Repurchase Behavior: Investigating the Moderating Effect of Consumer Characteristics, Journal of Marketing Research, 38(February), 131-142 (2001)

Mittal, V., and Niraj, R., Examining the Nonlineal Effects in Satisfaction-Loyalty-Behavioral Intentions Model, Indian Institute of Management, Working Papers, 2007-11-01, November (2007)

Mohr, J.J. and Spekman, R., Characteristics of Partnerships Success: Partnership Attributes, Communication, Behavior and Conflict Resolution Techniques, Strategic Management Journal 1, 135-152 (1994)

Moeller, S.; Fassnacht, M. and Klose, S. A Framework for Supplier Relationship Management (SRM), Journal of Business to Business Marketing, 13, 4, 69-94 (2006)

Morgan, R.M. and Hunt. S.D. The Commitment-Trust Theory of Relationship Marketing, Journal of Marketing 58, 20-38 (1994).

Narayandas, D., Building Loyalty in Business Markets, Harvard Business Review 83, 9, 131139 (2005)

Nevin, J.R., Relationship Marketing and Distribution Channels: Exploring Fundamental Issues, Journal of the Academy of Marketing Science 23, 4, 327-334, (1995)

Nguyen, N. and LeBlanc, G., Corporate Image and Corporate Reputation in Customers' Retention Decisions in Services, International Journal of Retailing and Consumer Service 8, 4, 227-236 (2001)

Nijssen, E.; Singh, J., Sirdeshmunkh, D. and Holzmüeller, H. Investigating Industry Context Effects in Consumer-Firm Relationships: Preliminary Results From a Dispositional Approach, Journal of the Academy of Marketing Science 31, 1, 46-60 (2003)

Nyer, P.U., A Study of the Relationships between Cognitive Appraisals and Consumption Emotions, Journal of the Academy of Marketing Science 25, 4, 296-304 (1997)

Oh, H., Price Fairness and Its Asymmetric Effects on Overall Price, Quality, and Value Judgments: the Case of an Upscale Hotel, Tourism Management 24, 241-249 (2003)

Oliver, R., Satisfaction: A Behavioral Perspective on the Consumer. New York Irwin/McGrawHill (1997)

Oliver, R., Whence consumer Loyalty?, Journal of Marketing 63, Special Issue, 33-45 (1999)

Olsen, S.O., Comparative Evaluation and the Relationship between Quality, Satisfaction, and Repurchase Loyalty, Journal of the Academy of Marketing Science 30, 3, 240-249 (2002)

Parasuraman, A., Reflections on Gaining Competitive Advantage Through Customer Value, Journal of The Academy of Marketing Science 25, 2, 154-161 (1997)

Prahalad, C.K. and V, Ramaswamy V, Co-creation experiences: The next practice in value creation, Journal of Interactive Marketing, 18:3, 5-15 (2004) 
Plank, R.E. and Newell, S.J., The Effect of Social Conflict on Relationship Loyalty in Business Markets, Industrial Marketing Management, 36, 1, 59-67 (2007)

Porter, M.E., Clusters and the New Economics of Competition, Harvard Business Review, November-December (1998)

Porter, M.E., Location, Clusters, and Company Strategy in Oxford Handbook of Economic Geography, Clark, Gertler and Feldman, Eds, Oxford, Oxford University Press (2000)

Price, L.; Arnauld, E. and Deibler, S.L., Consumers' emotional Responses to Service Encounters. The influence of the Service Provider, International Journal of Service Industry Management 6, 3, 34-63 (1995)

Ravald, A. and Grönroos, C., The Value Concept and Relationship Marketing, European Journal of Marketing 30, 2, 19-30 (1996)

Reichheld, F., The Loyalty Effect, The Hidden Force Behind Growth, Profits and Lasting Value. Boston, Harvard Business School Press (1996)

Rowley, J. and Dawes, J., Disloyalty: a Closer Look at Non-Loyals, Journal of Consumer Marketing 17, 6, 538-549 (2000).

Rust, R.; Zeithaml, V. and Lemmon, K., Driving Customer Equity, The Free Press, New York (2000)

Schmitt, B.H., Experiential Marketing, The Free Press (1999)

Sánchez, J and Moliner, M.A., Desarrollo de una investigación basada en modelos de Ecuaciones estructurales. Una comparación del análisis basado en variables latentes con el análisis path, in english, Development of an Investigation Based on Models of Structural Equations. A Comparison of the Analysis Based on Latent Variables with Path Analysis, Proceedings VIII Taller de Metodología ACEDE, Benicassim (Castellón), May 16-17th (2002)

Sandström, M., The Culture Influence on International Business Relationships, in M. Forsgren, \& J. Johanson (Eds.), Managing Networks in International Business (pp. 4760), Philadelphia:Gordon \& Breach (1992)

Sharma, A; Krishnan, R and Grewal, D., Value Creation in Markets. A Critical Area of Focus for Business-to-Business Markets, Industrial Marketing Management 30. 391-402 (2001)

Sharma, S; Durand, R.M. and Gur-Aire, O, Identification and Analysis of Moderator Variables, Journal of Marketing 58, 1, 46-55 (1981)

Sheth, J.N.; Newman, B.I. and Gross, B.L., Consumption Values and Market Choice. Cincinnati, Ohio: South Western Publishing (1991a)

Sheth, J.N.; Newman, B.I. and Gross, B.L., Why We Buy What We Buy: A Theory of Consumption Values, Journal of Business Research 22, 159-170 (1991b) 
Sinha, I. and DeSarbo, W.S., An Integrated Approach toward the Spatial Modeling of Perceived Customer Value, Journal of Marketing Research 35, 236-249 (1998)

Spiteri, J.M. and Dion, P.A., Customer value, overall satisfaction, end-user loyalty, and market performance in detail intensive industries, Industrial Marketing Management $33,8,675-687$ (2004)

Steemkamp, E.M. and Van Trijp, C.M., The Use of LISREL in Validating Marketing Constructs, International Journal of Research in Marketing 8, 283-299 (1991)

Sweeney, J.C.; Soutar, G. and Johnson, L.W., The Role of Perceived Risk in the QualityValue Relationship: A Study in a Retail Environment, Journal of Retailing 75, 1, 77105 (1999)

Sweeney, J.C. and Soutar, G., Consumer Perceived Value: The Development of Multiple Item Scale, Journal of Retailing 77, 2, 203-220 (2001)

Sweeney, J.C. and Webb, D., Relationship Benefits: An Exploration of Buyer-Supplier Dyads, Journal of Relationship Marketing 1, 2, 77-92 (2002)

Ulaga, W., Capturing value creation in business relationships: A customer perspective, Industrial Marketing Management 32, 677-693 (2003)

Ulaga, W. and Chacour, S., Measuring Customer-Perceived Value in Business Markets: A Prerequisite for Marketing Strategy Development and Implementation, Industrial Marketing Management 30, 525-540 (2001)

Ulaga, W. and Eggert, A., Developing a Standard Scale of Relationship Value in Business Markets: Development of a Measurement Scale, 17th Annual IMP Conference Proceedings, 1-38 (2003)

Ulaga, W. and Eggert, A., Value-Based Differentiation in Business Relationships: Gaining and Sustaining Key Suppliers Status, Journal of Marketing, January, 119-136 (2006)

Vargo, S.L. and Lusch, R.F., The Four Services Marketing Myths: Remnants from a Manufacturing Model, Journal of Service Research 6, 4, 324-335 (2004).

Walter, A.; Ritter, T. and Gemünden, H.G., Value Creation in buyer-Seller Relationships: Theoretical Considerations and Empirical Results from a Supplier's Perspective, Industrial Marketing Management 30, 365-377 (2001)

Wetzels, M; De Ruyter, K. and Van Birgelen, M. Marketing Service Relationships: The Role of Commitment, Journal of Business \& Industrial Marketing 13, 4/5, 406-423 (1998)

Wilson, D.T. An Integrated Model of Buyer-Seller Relationships, Journal of The Academy of Marketing Science 23, 4, 335-345 (1995)

Woodall, T., Conceptualising "Value for the Customer": An Attributional, Structural and Dispositional Analysis, Academy of Marketing Science Review, 12, 1-42 (2003)

Woodruff, R., Customer Value: The Next Source for Competitive Advantage, Journal of The Academy of Marketing Science 25,139-153 (1997) 
Yi, Y. and Jeon, H., Effects of Loyalty Programs on Value Perception, Program Loyalty and Brand Loyalty, Journal of the Academy of Marketing Science 31, 3, 229-240 (2003)

Zeithaml, V.A., Consumer Perceptions of Price, Quality, and Value: A Means-End Model and Synthesis of Evidence, Journal of Marketing 52, 2-22 (1988)

Zeithaml V.A., Berry, L.L. and Parasuraman, A., The Behavioral Consequences of Service Quality, Journal of Marketing, April, 31-46 (1996) 


\section{APPENDIX}

Table 1. Scales of measurement of the dimensions of customer's perceived value

\begin{tabular}{|l|l|l|}
\hline Variable & Number of items on scale & References \\
\hline $\begin{array}{l}\text { Functional value } \\
\text { technical quality } \\
\text { of product }\end{array}$ & $\begin{array}{l}\text { Durable quality: } 3 \text { items } \\
\text { Technical quality: } 3 \text { items }\end{array}$ & $\begin{array}{l}\text { Lapierre (2000), Ulaga and } \\
\text { Chacour (2001), Ulaga and } \\
\text { Eggert (2002); Spiteri and Dion } \\
\text { (2004) }\end{array}$ \\
\hline $\begin{array}{l}\text { Functional value } \\
\text { firm's quality of } \\
\text { service }\end{array}$ & $\begin{array}{l}\text { Tangibility and technical competence: } 7 \\
\text { items } \\
\text { Reliability: } 5 \text { items } \\
\text { Security: } 3 \text { items } \\
\text { Lapierre (2000). }\end{array}$ \\
\hline $\begin{array}{l}\text { Functional value } \\
\text { employees' } \\
\text { quality of service }\end{array}$ & Employees: 4 items & $\begin{array}{l}\text { Lapierre (2000), Cronin, Brady } \\
\text { and Hult (2000). }\end{array}$ \\
\hline $\begin{array}{l}\text { Functional value } \\
\text { Sacrifices }\end{array}$ & $\begin{array}{l}\text { Price: } 4 \text { items } \\
\text { Convenience: } 4 \text { items } \\
\text { Costs of change: } 2 \text { items }\end{array}$ & $\begin{array}{l}\text { Lapierre (2000), Sweeney and } \\
\text { Soutar (2001), Lusch and Brown } \\
\text { Reputation: } 3 \text { items } \\
\text { (1996) }\end{array}$ \\
\hline Social value & $\begin{array}{l}\text { Lapierre (2000), Nguyen and } \\
\text { Leblanc (2001), Sweeney and } \\
\text { Soutar (2001). }\end{array}$ \\
\hline Emotional value & $\begin{array}{l}\text { Experience: } 5 \text { items } \\
\text { Personalized attention: } 2 \text { items } \\
\text { Interpersonal relationships: } 5 \text { items }\end{array}$ & $\begin{array}{l}\text { Henning-Thurau, Gwinner and } \\
\text { Gremler (2002); Lapierre (2000), } \\
\text { Sweeney and Soutar (2001), }\end{array}$ \\
\hline Satisfaction & General satisfaction: 1 item & Andaleeb (1996) \\
\hline Loyalty & $\begin{array}{l}\text { Intentions to repurchase: } 1 \text { item } \\
\text { Positive references: } 1 \text { item } \\
\text { Low sensitivity to price: } 1 \text { item }\end{array}$ & $\begin{array}{l}\text { Zeithaml, Parasuraman and } \\
\text { Berry, (1996), Cronin, Brady and } \\
\text { Hult (2000) }\end{array}$ \\
\hline
\end{tabular}


Table 2. Confirmatory Factor Analysis of the functional value quality of product

\begin{tabular}{|l|c|}
\hline \multicolumn{1}{|c|}{ DURABLE QUALITY OF PRODUCT } & FACTOR LOADINGS \\
\hline The reliability of the products purchased increases with the passage of time & 0.77 \\
\hline $\begin{array}{l}\text { The quality of the products acquired from the supplier increases with the } \\
\text { passage of time }\end{array}$ & 0.74 \\
\hline $\begin{array}{l}\text { The yield obtained over time with the products acquired is a determining } \\
\text { factor in acquiring them }\end{array}$ & 0.60 \\
\hline \multicolumn{1}{|c|}{ TECHNICAL QUALITY OF PRODUCT } & FACTOR LOADINGS \\
\hline $\begin{array}{l}\text { The technical specifications of the supplier's products are adequate for our } \\
\text { requirements }\end{array}$ & 0.64 \\
\hline The supplier firm offers me the best products & 0.64 \\
\hline The products acquired from the supplier are easy to use & 0.62 \\
\hline $\begin{array}{l}\text { FIT OF THE MODEL: Chi-Squared= 21.72; gl= 14; P-value=0.08458; RMSEA= } 0.074 ; \text { GFI= } 0.93 ; \\
\text { AGFI=0.90 }\end{array}$ & \\
\hline $\begin{array}{l}\text { COMPOSITE RELIABILITY: Composite reliability of quality associated with passage of time }= \\
\text { 0.7480; Composite reliability of technical quality = 0.6638; Overall composite reliability =0.8287 }\end{array}$ \\
\hline $\begin{array}{l}\text { DISCRIMINANT VALIDITY (correlation between factors and in brackets the confidence interval of the } \\
\text { correlation): 0.84 (0.70-0.97) }\end{array}$ \\
\hline
\end{tabular}


Table 3. Confirmatory factor analysis of the functional value firm's service quality

\begin{tabular}{|c|c|}
\hline TANGIBILITY- TECHNICAL COMPETENCE & FACTOR LOADINGS \\
\hline $\begin{array}{l}\text { Our main supplier is very creative and innovative in the products and } \\
\text { services offered }\end{array}$ & 0.83 \\
\hline $\begin{array}{l}\text { Our main supplier stands out for its special expertise in its activity in the } \\
\text { industry }\end{array}$ & 0.83 \\
\hline $\begin{array}{l}\text { Our main supplier stands out for the way it uses new technology to generate } \\
\text { solutions }\end{array}$ & 0.83 \\
\hline $\begin{array}{l}\text { Our main supplier stands out for its capacity to provide systematic solutions } \\
\text { in response to our problems }\end{array}$ & 0.77 \\
\hline $\begin{array}{l}\text { Our main supplier stands out for its capacity to demonstrate wide knowledge } \\
\text { of the processes of our business }\end{array}$ & 0.74 \\
\hline $\begin{array}{l}\text { In general, the appearance of our supplier's physical installations and } \\
\text { employees is nice and clean }\end{array}$ & 0.64 \\
\hline $\begin{array}{l}\text { In general, in our main supplier they strive to understand and attend to our } \\
\text { needs }\end{array}$ & 0.64 \\
\hline $\begin{array}{c}\text { RELIABILITY } \\
\end{array}$ & FACTOR LOADINGS \\
\hline Our main supplier offers us fast and flexible service & 0.83 \\
\hline Our main supplier stands out for its skill in doing things right first time & 0.83 \\
\hline $\begin{array}{l}\text { Our main supplier scrupulously fulfils the delivery dates of orders or the } \\
\text { performance of the services agreed }\end{array}$ & 0.83 \\
\hline Our main supplier's invoices are accurate and clear & 0.61 \\
\hline Our main supplier knows how to deal with our complaints & 0.58 \\
\hline $\begin{array}{c}\text { SECURITY } \\
\end{array}$ & FACTOR LOADINGS \\
\hline $\begin{array}{l}\text { For our firm the accuracy of the information from our supplier is very } \\
\text { important }\end{array}$ & 0.77 \\
\hline $\begin{array}{l}\text { For our firm the fulfilment of the promises made by the supplier is very } \\
\text { important }\end{array}$ & 0.77 \\
\hline $\begin{array}{l}\text { For our firm the technical advice offered by the supplier for the management } \\
\text { of our business is very important }\end{array}$ & 0.74 \\
\hline \multicolumn{2}{|c|}{$\begin{array}{l}\text { FIT OF THE MODEL: Chi-Squared }=124.18 ; \mathrm{gl}=100 ; \mathrm{P} \text {-value }=0.05101 ; \mathrm{RMSEA}=0.049 ; \mathrm{GFI}= \\
0.86 ; \mathrm{AGFI}=0.83\end{array}$} \\
\hline \multicolumn{2}{|c|}{$\begin{array}{l}\text { COMPOSITE RELIABILITY: Composite reliability of tangibility- Technical comp. }=0.9037 ; \\
\text { Composite reliability of reliability }=0.8581 ; \text { Composite reliability of security }=0.8037 ; \text { Reliability of } \\
\text { total quality of service }=0.9512\end{array}$} \\
\hline \multicolumn{2}{|c|}{$\begin{array}{l}\text { DISCRIMINANT VALIDITY (correlation between factors and in brackets the confidence interval of the } \\
\text { correlation): } \\
\text { Tangib- technical comp. Reliability: } 0.74(0.57-0.93) \\
\text { Tangib- technical comp. Security: } 0.54(0.40-0.68) \\
\text { Reliability Security: } 0.35(0.21-0.49)\end{array}$} \\
\hline
\end{tabular}

Table 4. Confirmatory factor analysis of the functional value firm's employees

\begin{tabular}{|l|c|}
\hline \multicolumn{1}{|c|}{ EMPLOYEES' SERVICE QUALITY } & $\begin{array}{c}\text { FACTOR } \\
\text { LOADINGS }\end{array}$ \\
\hline $\begin{array}{l}\text { In general, the employees of our main supplier firm offer me a reliable and } \\
\text { consistent service }\end{array}$ & 0.92 \\
\hline $\begin{array}{l}\text { In general, the employees of our main supplier firm are competent and } \\
\text { professional }\end{array}$ & 0.92 \\
\hline $\begin{array}{l}\text { In general, the employees of our main supplier firm are accessible and it is } \\
\text { easy to contact them }\end{array}$ & 0.71 \\
\hline In general, the employees of our main supplier firm are polite and respectful & 0.65 \\
\hline $\begin{array}{l}\text { FIT OF THE MODEL: Chi-Squared=12.35; gl=7; P-value=0.08958; RMSEA=0.087; GFI=0.94; } \\
\text { AGFI=0.91 }\end{array}$ \\
\hline COMPOSITE RELIABILITY: 0.8828 \\
\hline
\end{tabular}


Customer loyalty in clusters: perceived value and satisfaction as antecedents 
Table 5. Confirmatory factor analysis of the functional value sacrifices

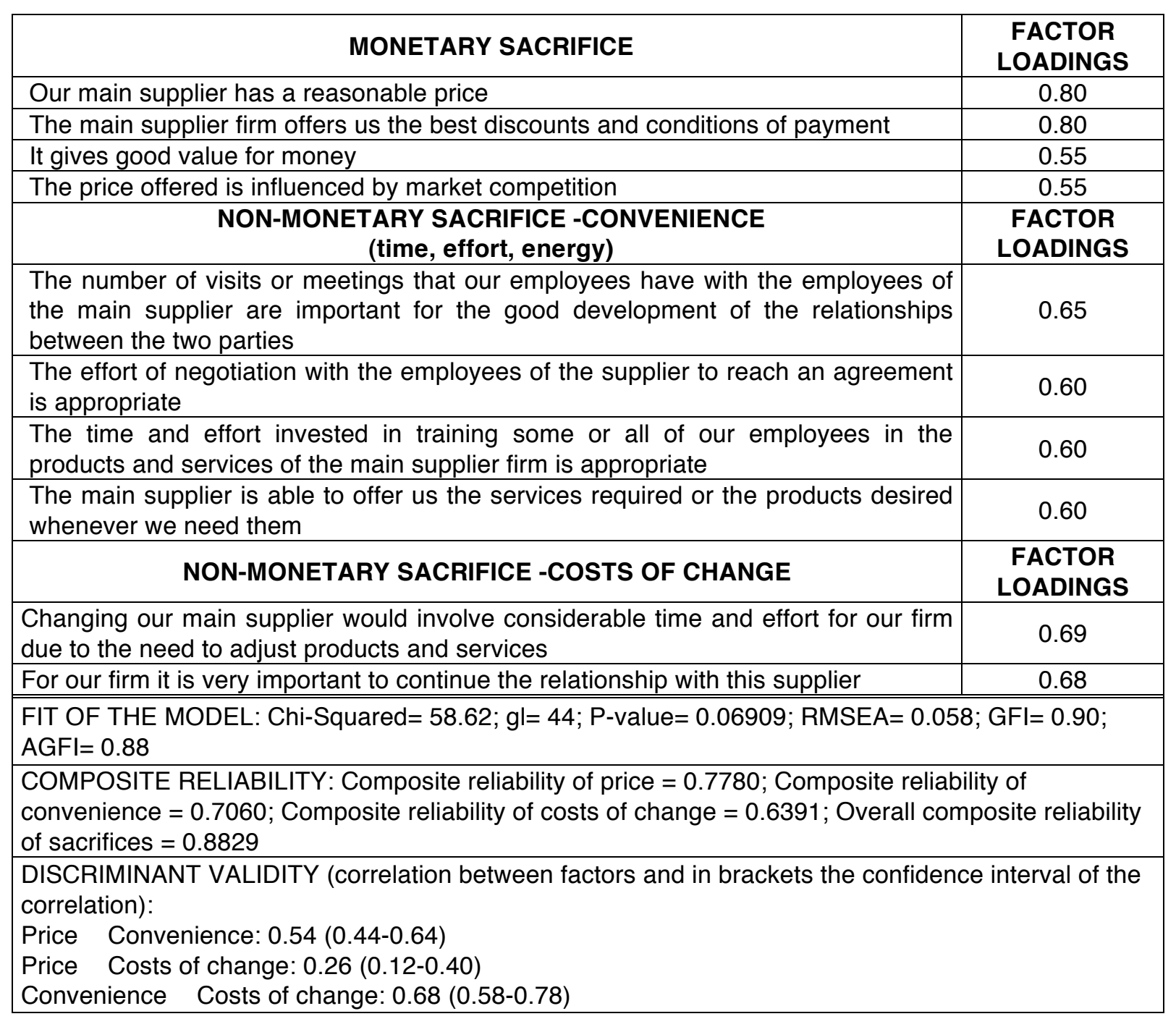

Table 6. Confirmatory factor analysis of social value

\begin{tabular}{|l|c|}
\hline \multicolumn{1}{|c|}{ SOCIAL IMAGE } & FACTOR LOADINGS \\
\hline Our main supplier has a reputation for good social behaviour & 0.83 \\
\hline $\begin{array}{l}\text { I consider that our main supplier behaves ethically towards its customers and } \\
\text { employees }\end{array}$ & 0.81 \\
\hline $\begin{array}{l}\text { Generally, I read and pay attention to all the information that our main supplier } \\
\text { sends me }\end{array}$ & 0.56 \\
\hline Our supplying firm participates actively in social events & 0.55 \\
\hline \multicolumn{1}{|c|}{ REPUTATION } & FACTOR LOADINGS \\
\hline $\begin{array}{l}\text { The general credibility of our main supplier helps to improve the image of our } \\
\text { firm }\end{array}$ & 0.92 \\
\hline $\begin{array}{l}\text { The general reputation of our main supplier fits with the image of our firm that } \\
\text { we want to present }\end{array}$ & 0.79 \\
\hline $\begin{array}{l}\text { The relationship with our main supplier improves the social perception of our } \\
\text { firm }\end{array}$ & 0.77 \\
\hline $\begin{array}{l}\text { FIT OF THE MODEL: Chi-Squared= 19.74; gl= 14; P-value= } \\
\text { AGFI=0.89 }\end{array}$ & $\begin{array}{l}\text { COMPOSITE RELIABILITY: Composite reliability of factor } 1=0.8103 ; \text { RMSEmposite reliability of factor } 2 \\
=0.8674 ; \text { Total composite reliability =0.9017 }\end{array}$ \\
\hline
\end{tabular}


Customer loyalty in clusters: perceived value and satisfaction as antecedents

DISCRIMINANT VALIDITY (correlation between factors and in brackets the confidence interval of correlation): 0.59 (0.41-077) 
Table 7. Confirmatory factor analysis of emotional value

\begin{tabular}{|c|c|}
\hline EXPERIENCE & $\begin{array}{l}\text { FACTOR } \\
\text { LOADINGS }\end{array}$ \\
\hline $\begin{array}{l}\text { The ease of use of the products/services of our main supplier favours the } \\
\text { desire to use them }\end{array}$ & 0.72 \\
\hline $\begin{array}{l}\text { The experience with the supplier seems to us a determining factor in the } \\
\text { relationship }\end{array}$ & 0.61 \\
\hline Our supplier, in general, knows in advance what we need & 0.51 \\
\hline Our main supplier's experience enables it to offer the best advice & 0.61 \\
\hline This supplier is an expert in its field & 0.70 \\
\hline \multicolumn{2}{|l|}{ PERSONALISED ATTENTION } \\
\hline The employees of our supplier recognise me when I deal v & 0.70 \\
\hline In the supplier firm they know my name & 0.70 \\
\hline \multicolumn{2}{|l|}{ INTERPERSONAL RELATIONSHIPS } \\
\hline Relationships with our main supplier are pleasant & 0.70 \\
\hline $\begin{array}{l}\text { Bonds of friendship have developed between the main supplier's employees } \\
\text { and ours when they visit us or vice versa }\end{array}$ & 0.70 \\
\hline Relationships and dealings with our main supplier's employees are pleasant & 0.74 \\
\hline $\begin{array}{l}\text { In general, interacting with our main supplier produces positive feelings that I } \\
\text { don't think we would have if we had no contact with it }\end{array}$ & 0.62 \\
\hline The evolution of the relationship with our supplier seems positive & 0.70 \\
\hline \multicolumn{2}{|c|}{$\begin{array}{l}\text { FIT OF THE MODEL: Chi-Squared= 86.26; gl= 68; P-value=0.06674; RMSEA=0.052; GFI=0.87; } \\
\text { AGFI=0.86 }\end{array}$} \\
\hline \multicolumn{2}{|c|}{$\begin{array}{l}\text { COMPOSITE RELIABILITY: Composite reliability of experience }=0.7521 \text {; Composite reliability of } \\
\text { personalized attention }=0.6577 \text {; Composite reliability of interpersonal relationships }=0.8238 \text {; Overall } \\
\text { composite reliability of total emotional value }=0.8684\end{array}$} \\
\hline \multicolumn{2}{|c|}{$\begin{array}{l}\text { DISCRIMINANT VALIDITY (correlation between factors and in brackets the confidence interval of the } \\
\text { correlation): } \\
\text { Experience personalized attention: } 0.27(0.15-0.39) \\
\text { Experience interpersonal relationships: } 0.39(0.27-0.51) \\
\text { personalized attention interpersonal relationships: } 0.39(0.27-0.51)\end{array}$} \\
\hline
\end{tabular}


Table 8. Confirmatory factor analysis of total perceived value

\begin{tabular}{|c|c|}
\hline TOTAL PERCEIVED VALUE & FACTOR LOADINGS \\
\hline \multicolumn{2}{|c|}{ Functional Value } \\
\hline Price (SACM) & 0.62 \\
\hline Convenience (SACONV) & 0.69 \\
\hline Costs of change (SACC) & 0.54 \\
\hline Product quality (BFCP) & 0.76 \\
\hline Quality of employees (BFCPEMPL) & 0.76 \\
\hline Firm's service quality (BFCEMP) & 0.84 \\
\hline \multicolumn{2}{|c|}{ Social Value } \\
\hline Social image (VSIMG) & 0.75 \\
\hline Reputation (VSREP) & 0.75 \\
\hline \multicolumn{2}{|c|}{ Emotional Value } \\
\hline Experience (VEEXP) & 0.89 \\
\hline Personalised attention (VETP) & 0.58 \\
\hline Interpersonal relations (VERI) & 0.80 \\
\hline \multirow{2}{*}{\multicolumn{2}{|c|}{$\begin{array}{l}\text { FIT OF THE MODEL: Chi-Squared }=72.88 ; \mathrm{gl}=55 ; \mathrm{P} \text {-value }=0.05361 ; \mathrm{RMSEA}=0.057 ; \mathrm{GFI}=0.88 \text {; } \\
\text { AGFI= } 0.86 \\
\text { COMPOSITE RELIABILITY: Composite reliability of emotional value }=0.8556 ; \text { Composite reliability of } \\
\text { social value }=0.7188 ; \text { Composite reliability of emotional value }=0.8086 ; \text { overall composite Reliability of } \\
\text { perceived value }=0.9260\end{array}$}} \\
\hline & \\
\hline \multicolumn{2}{|c|}{$\begin{array}{l}\text { DISCRIMINANT VALIDITY (correlation between the factors and in brackets the confidence interval of } \\
\text { the correlation): } \\
\text { Functional value Social value: } 0.55(0.35-0.75 \mathrm{~F} \\
\text { Functional value Emotional value: } 0.69(0.47-0.91) \\
\text { Social value Emotional value: } 0.55(0.35-0.75)\end{array}$} \\
\hline
\end{tabular}

Table 9.Confirmatory factor analysis of the customer's loyalty

\begin{tabular}{|c|c|c|}
\hline & $\begin{array}{l}\text { FACTOR } \\
\text { LOADINGS }\end{array}$ \\
\hline LEAL1 & $\begin{array}{l}\text { Our intention is to continue the relationship with this supplier in the } \\
\text { long term }\end{array}$ & 0.82 \\
\hline LEAL2 & If I am asked, I recommend our supplier firm & 0.82 \\
\hline $\begin{array}{l}\text { Chi-Squa } \\
\text { Composi }\end{array}$ & $\begin{array}{l}\text { Ired }=0.06 ; g l=1 ; P \text {-value }=0.80305 ; \text { RMSEA }=0.01 ; G F I=0.99 ; A G F I \\
\text { te reliability }=0.8030\end{array}$ & \\
\hline
\end{tabular}

Table 10. Comparative model with different number of suppliers

\begin{tabular}{|l|c|c|}
\hline Relationship & P-value & Chi-Square \\
\hline Overall & 0.42087 & 6.02 \\
\hline Satisfaction $\rightarrow$ Loyalty & 0.37493 & 5.35 \\
\hline Value $\rightarrow$ Satisfaction & 0.36444 & 5.44 \\
\hline Value $\rightarrow$ Loyalty & 0.44983 & 4.73 \\
\hline
\end{tabular}


Table 11. Scales of measurement of the perceived value

\begin{tabular}{|c|c|}
\hline \multicolumn{2}{|c|}{ FUNCTIONAL VALUE } \\
\hline & QUALITY OF THE PRODUCT \\
\hline & $\begin{array}{l}\text { DURABLE QUALITY OF PRODUCT } \\
\end{array}$ \\
\hline VF1 & The reliability of the products purchased increases with the passage of time \\
\hline VF2 & The quality of the products acquired from the supplier increases with the passage of time \\
\hline \multirow[t]{2}{*}{ VF3 } & $\begin{array}{l}\text { The yield obtained over time with the products acquired is a determining factor in acquiring } \\
\text { them }\end{array}$ \\
\hline & \begin{tabular}{|l} 
TECHNICAL QUALITY OF PRODUCT \\
\end{tabular} \\
\hline VF4 & The technical specifications of the supplier's products are adequate for our requirements \\
\hline VF5 & The supplier firm offers me the best products \\
\hline \multirow[t]{3}{*}{ VF6 } & The products acquired from the supplier are easy to use \\
\hline & COMPANY'S SERVICE QUALITY \\
\hline & \begin{tabular}{|c|} 
TANGIBILITY- TECHNICAL COMPETENCE \\
\end{tabular} \\
\hline VF7 & Our main supplier is very creative and innovative in the products and services offered \\
\hline VF8 & Our main supplier stands out for its special expertise in its activity in the industry \\
\hline VF9 & Our main supplier stands out for the way it uses new technology to generate solutions \\
\hline VF10 & $\begin{array}{l}\text { Our main supplier stands out for its capacity to provide systematic solutions in response to } \\
\text { our problems }\end{array}$ \\
\hline VF11 & $\begin{array}{l}\text { Our main supplier stands out for its capacity to demonstrate wide knowledge of the processes } \\
\text { of our business }\end{array}$ \\
\hline VF12 & $\begin{array}{l}\text { In general, the appearance of our supplier's physical installations and employees is nice and } \\
\text { clean }\end{array}$ \\
\hline \multirow[t]{2}{*}{ VF13 } & In general, in our main supplier they strive to understand and attend to our needs \\
\hline & \begin{tabular}{|c|} 
RELIABILITY \\
\end{tabular} \\
\hline VF14 & Our main supplier offers us fast and flexible service \\
\hline VF15 & Our main supplier stands out for its skill in doing things right first time \\
\hline VF16 & $\begin{array}{l}\text { Our main supplier scrupulously fulfils the delivery dates of orders or the performance of the } \\
\text { services agreed }\end{array}$ \\
\hline VF17 & Our main supplier's invoices are accurate and clear \\
\hline \multirow[t]{2}{*}{ VF18 } & Our main supplier knows how to deal with our complaints \\
\hline & \begin{tabular}{|c|} 
SECURITY \\
\end{tabular} \\
\hline VF19 & For our firm the accuracy of the information from our supplier is very important \\
\hline VF20 & For our firm the fulfilment of the promises made by the supplier is very important \\
\hline \multirow[t]{2}{*}{ VF21 } & $\begin{array}{l}\text { For our firm the technical advice offered by the supplier for the management of our business } \\
\text { is very important }\end{array}$ \\
\hline & EMPLOYEES' SERVICE QUALITY \\
\hline VF22 & In general, the employees of our main supplier firm offer me a reliable and consistent service \\
\hline VF23 & In general, the employees of our main supplier firm are competent and professional \\
\hline VF24 & $\begin{array}{l}\text { In general, the employees of our main supplier firm are accessible and it is easy to contact } \\
\text { them }\end{array}$ \\
\hline \multirow[t]{3}{*}{ VF25 } & In general, the employees of our main supplier firm are polite and respectful \\
\hline & SACRIFICES \\
\hline & MONETARY SACRIFICE \\
\hline VF26 & Our main supplier has a reasonable price \\
\hline VF27 & The main supplier firm offers us the best discounts and conditions of payment \\
\hline VF28 & It gives good value for money \\
\hline \multirow[t]{2}{*}{ VF29 } & The price offered is influenced by market competition \\
\hline & $\begin{array}{c}\text { NON-MONETARY SACRIFICE -CONVENIENCE } \\
\text { (time, effort, energy) }\end{array}$ \\
\hline
\end{tabular}




\begin{tabular}{|c|c|}
\hline VF30 & $\begin{array}{l}\text { The number of visits or meetings that our employees have with the employees of the main } \\
\text { supplier are important for the good development of the relationships between the two parties }\end{array}$ \\
\hline VF31 & $\begin{array}{l}\text { The effort of negotiation with the employees of the supplier to reach an agreement is } \\
\text { appropriate }\end{array}$ \\
\hline VF32 & $\begin{array}{l}\text { The time and effort invested in training some or all of our employees in the products and } \\
\text { services of the main supplier firm is appropriate }\end{array}$ \\
\hline \multirow[t]{2}{*}{ VF33 } & $\begin{array}{l}\text { The main supplier is able to offer us the services required or the products desired whenever } \\
\text { we need them }\end{array}$ \\
\hline & $\begin{array}{l}\text { NON-MONETARY SACRIFICE -COSTS OF CHANGE } \\
\end{array}$ \\
\hline VF34 & $\begin{array}{l}\text { Changing our main supplier would involve considerable time and effort for our firm due to the } \\
\text { need to adjust products and services }\end{array}$ \\
\hline VF35 & For our firm it is very important to continue the relationship with this supplier \\
\hline \multicolumn{2}{|c|}{ SOCIAL VALUE } \\
\hline & SOCIAL IMAGE \\
\hline VS1 & Our main supplier has a reputation for good social behaviour \\
\hline VS2 & I consider that our main supplier behaves ethically towards its customers and employees \\
\hline VS3 & Generally, I read and pay attention to all the information that our main supplier sends me \\
\hline \multirow[t]{2}{*}{ VS4 } & Our supplying firm participates actively in social events \\
\hline & REPUTATION \\
\hline VS5 & The general credibility of our main supplier helps to improve the image of our firm \\
\hline VS6 & $\begin{array}{l}\text { The general reputation of our main supplier fits with the image of our firm that we want to } \\
\text { present }\end{array}$ \\
\hline VS7 & The relationship with our main supplier improves the social perception of our firm \\
\hline \multicolumn{2}{|c|}{ EMOTIONAL VALUE } \\
\hline & EXPERIENCE \\
\hline VE1 & The ease of use of the products/services of our main supplier favors the desire to use them \\
\hline VE2 & The experience with the supplier seems to us a determining factor in the relationship \\
\hline VE3 & Our supplier, in general, knows in advance what we need \\
\hline VE4 & Our main supplier's experience enables it to offer the best advice \\
\hline \multirow[t]{2}{*}{ VE5 } & This supplier is an expert in its field \\
\hline & $\begin{array}{c}\text { PERSONALISED ATTENTION } \\
\end{array}$ \\
\hline VE6 & The employees of our supplier recognize me when I deal with them \\
\hline \multirow[t]{2}{*}{ VE7 } & In the supplier firm they know my name \\
\hline & $\begin{array}{l}\text { INTERPERSONAL RELATIONSHIPS } \\
\end{array}$ \\
\hline VE8 & Relationships with our main supplier are pleasant \\
\hline VE9 & $\begin{array}{l}\text { Bonds of friendship have developed between the main supplier's employees and ours when } \\
\text { they visit us or vice versa }\end{array}$ \\
\hline VE10 & Relationships and dealings with our main supplier's employees are pleasant \\
\hline VE11 & $\begin{array}{l}\text { In general, interacting with our main supplier produces positive feelings that I don't think we } \\
\text { would have if we had no contact with it }\end{array}$ \\
\hline VE12 & The evolution of the relationship with our supplier seems positive \\
\hline
\end{tabular}

Table 12. Scales of measurement for satisfaction

\begin{tabular}{|l|l|}
\hline & \multicolumn{1}{|c|}{ SATISFACTION } \\
\hline SAT1 & $\begin{array}{l}\text { In general, we consider ourselves to be satisfied with the services given by our principal } \\
\text { providing company. }\end{array}$ \\
\hline
\end{tabular}

Table 13. Scales of measurement for loyalty

\begin{tabular}{|l|l|}
\hline & \multicolumn{1}{|c|}{ LOYALTY } \\
\hline LEAL1 & Our intention is to continue the relationship with this supplier in the long term \\
\hline
\end{tabular}


Customer loyalty in clusters: perceived value and satisfaction as antecedents

\begin{tabular}{|l|l|}
\hline LEAL2 & If I am asked, I recommend our supplier firm \\
\hline
\end{tabular}

LEAL3 We prefer paying a bit more in exchange for the benefits that there offers us our providing company 
Figure 1: Proposed model and hypothesis

\section{CLUSTER ENVIRONMENT}

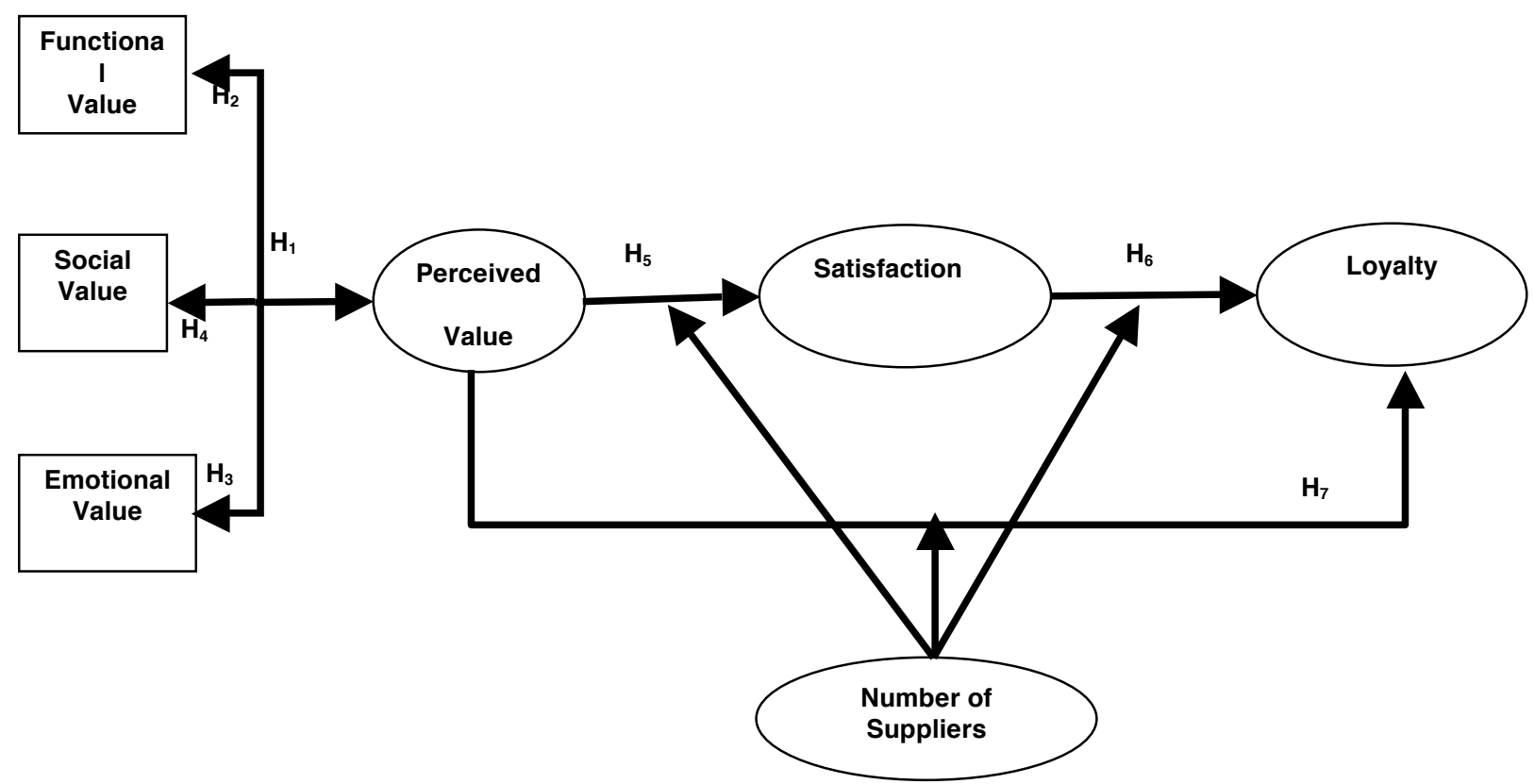


Figure 2. Second order confirmatory factor analysis of the total perceived value of the firm

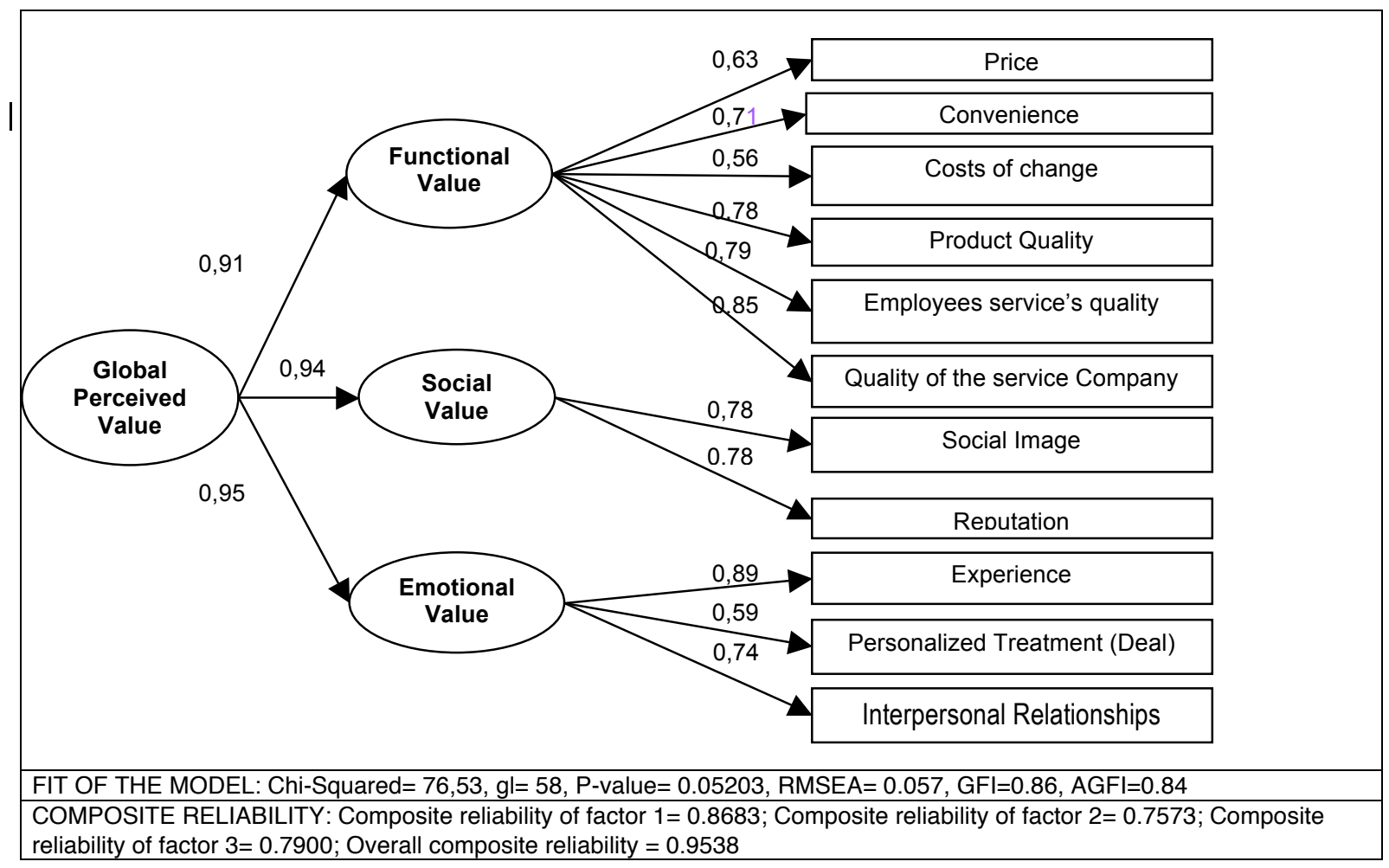


Customer loyalty in clusters: perceived value and satisfaction as antecedents

Figure 3: Results of the proposed overall model

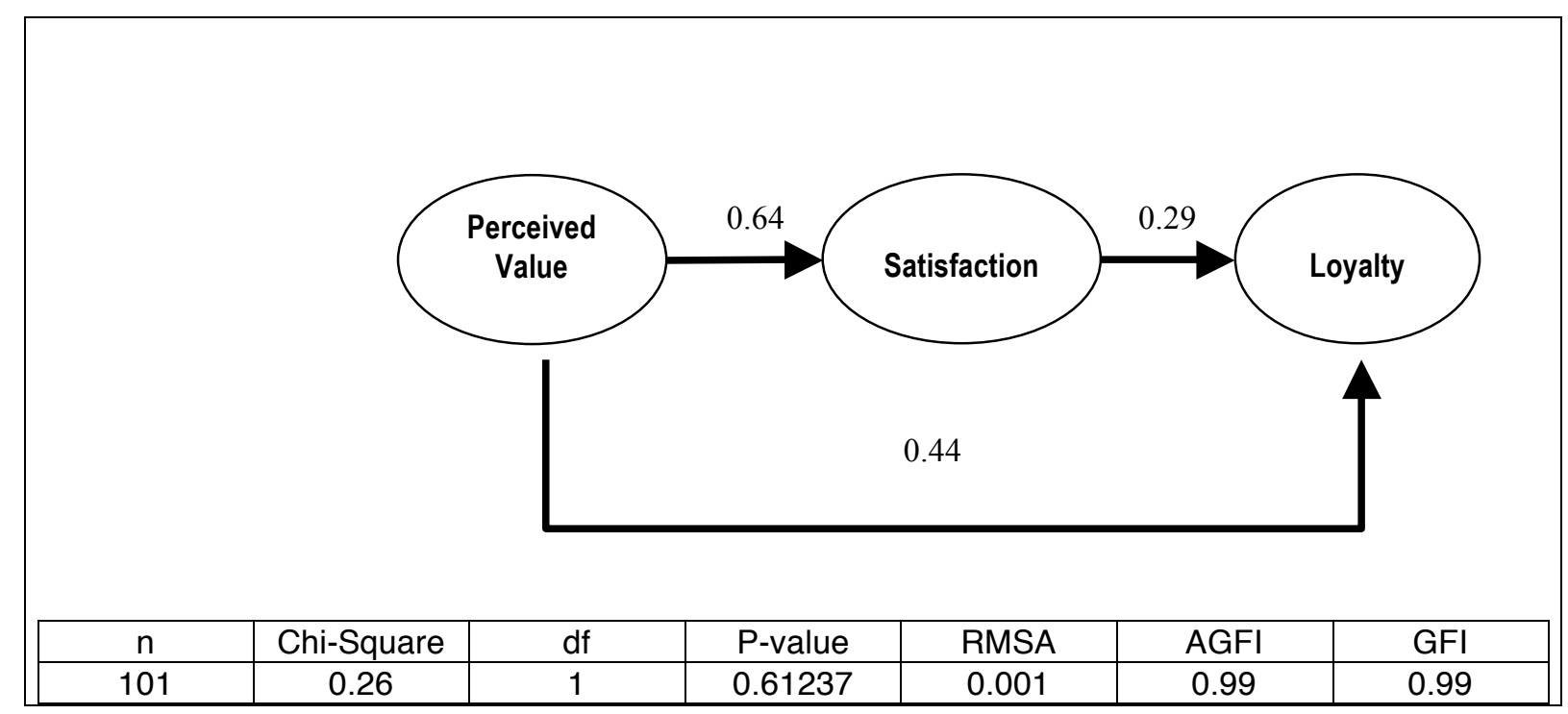


Figure 4: Results of the proposed overall model with the moderating variable "number of suppliers"

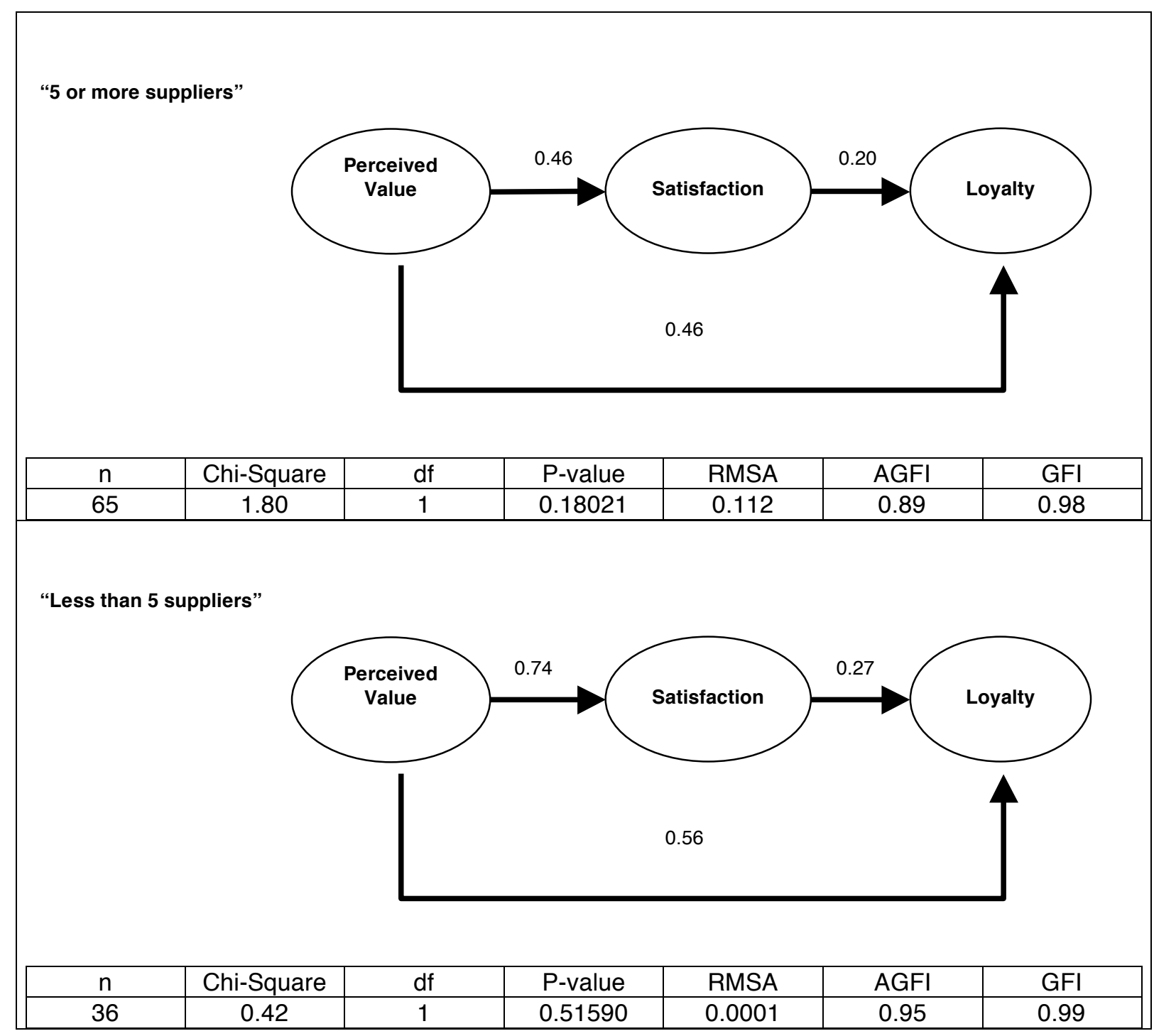

